\title{
THE RUSSIAN REVOLUTION OF 1917 THROUGH THE PRISM OF DEMOGRAPHIC MODERNIZATION *
}

\author{
BORIS MIRONOV
}

\begin{abstract}
In late imperial Russia demographic indicators improved, the efficiency of population replacement increased somewhat, a certain rationalization of demographic behavior occurred, and intra-familial relations were humanized. But arguably the most important changes were that a significant part of the population began to differentiate sexual, matrimonial, and reproductive behavior and to develop individual birth control, changes regarded in demography as criteria for the first demographic transition. The primary explanation for these positive changes lies in the participation in this demographic revolution of approximately 14 percent of Russian citizens, mainly from the educated and affluent population living in large cities, as well as Jewish, Catholic, and Protestant residents of the western regions. The majority of the rural and urban population, of Orthodox, Muslim, pagan, and other non-Christian religious affiliations (approximately 86 percent of the entire population), was superficially affected by the new trends. People who were actively and consciously drawn into the demographic transition, who had been transformed psychologically, mentally, and culturally, were also receptive to innovation in the social, political, cultural, and economic spheres and were the most prepared for and willing to refashion social life on a bourgeois-democratic basis. Their numbers were sufficient for the slow, gradual, overall modernization of the country, but inadequate for rapid and profound revolutionary bourgeois-democratic transformations. Consequently, the Revolution of 1917 proved premature. Political midwives hurried and artificially hastened the birth of a new Russia. The newborn was born preterm. As a result, the revolution could not meet the challenges set by its leaders and organizers.
\end{abstract}

Key words: nuptiality, fertility, mortality, efficiency of population replacement, birth control, illegitimate children, premarital sex, abortion, contraception, divorce, demographic transition.

The purpose of this article is to sum up the results of demographic modernization in late imperial Russia and, based on these results, to assess the population's readiness for the radical bourgeoisdemocratic transformations of society that the revolution of 1917 aimed to bring about.

Analysis of the main demographic processes in imperial Russia show that, in the 18th and the first half of the 19th century, marriage and fertility rates were at extremely high levels, mortality was also high, and all indicators, though they varied significantly in certain years, showed no clear tendency either to increase or decrease, conforming to the typical model of traditional population replacement (Table 1).

\footnotetext{
Boris N. Mironov (bmironov@mail.wplus.net), St. Petersburg State University, Russia.

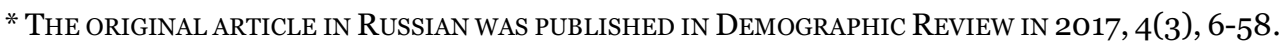
DOI: 10.17323/DEMREVIEW.V4I3.7316
}

THIS RESEARCH WAS SUPPORTED BY GRANT N 15-18-O0119 FROM RUSSIAN SCIENCE FOUNDATION. 
Table 1. Crude rates of nuptiality, fertility, mortality and natural population increase in European Russia in the 18th-early $20^{\text {th }}$ century, per thousand

\begin{tabular}{l|c|r|r|r|r|r|r|r}
\hline \multirow{2}{*}{ Demographic processes } & \multirow{2}{*}{$\begin{array}{c}18^{\text {th }} \\
\text { century* }\end{array}$} & \multicolumn{7}{|c}{ Years } \\
\cline { 3 - 9 } & & $\begin{array}{c}1801- \\
1860 *\end{array}$ & $\begin{array}{c}1861- \\
1870\end{array}$ & $\begin{array}{c}1871- \\
1880\end{array}$ & $\begin{array}{c}1881- \\
1890\end{array}$ & $\begin{array}{c}1891- \\
1900\end{array}$ & $\begin{array}{c}1901- \\
1910\end{array}$ & $\begin{array}{c}1911- \\
1914\end{array}$ \\
\hline Whole population: & & & & & & & & \\
nuptiality & 9.9 & 10.2 & 10.3 & 9.5 & 9.1 & 9.0 & 8.4 & 8.0 \\
fertility & 51.0 & 50.0 & 50.3 & 50.4 & 50.4 & 49.2 & 46.8 & 43.9 \\
mortality & 37.0 & 36.0 & 36.9 & 36.4 & 35.5 & 34.2 & 30.3 & 27.1 \\
natural increase & 14.0 & 14.0 & 13.3 & 14.0 & 14.9 & 15.1 & 16.5 & 16.8 \\
\hline
\end{tabular}

* Only the Orthodox population.

Sources: [Dvizhenie naseleniya... 1865; Mironov 2014: vol.1: 533-534; 1990: 259-260; Novoselsky 1916a: 36-37; Sifman 1977; Statistical Yearbook ... 1915: 2; Statistical yearbook ... 1918: 193].

Ten years after the abolition of serfdom the marriage rate began to decline steadily, and fertility and mortality began to decline a decade after that (starting in the 1880s). The decline in demographic indicators after the Great Reforms of the 1860s was in fact more pronounced than the data indicates, due to the improvement in the quality of demographic record-keeping, which contributed to an increase in the absolute value of demographic indicators. Two trends - a decrease in the absolute value of crude rates and an improvement in the quality of accounting (especially in the case of mortality) - cancelled each other out, and as a result the true picture was somewhat distorted. As a result of a more significant drop in mortality than in fertility, the already high rates of natural population growth began to increase, and on the eve of the First World War increased by 3.5 points - from 13.3 to 16.8 per thousand, reaching a maximum for the entire period of the empire, although during the war years these figures naturally decreased [Boyarskiy 1975]. The intensification of pressure on resources together with overall growth in the cultural level of the population created the prerequisites for a transition from the traditional to the modern model of demographic reproduction.

\section{MARRIAGE AND FAMILY}

The model of nuptiality changed during the the $18^{\text {th }}$ and first half of the $19^{\text {th }}$ century due to a rise in the age of marriage, and in the post-reform period due to an increase in the number of persons who did not marry, the growth of divorces, and a reduction in the number of people who remarried. In the second half of the $19^{\text {th }}$ century, the population became more tolerant than before of celibacy and delayed marriage and divorce, while so-called common-law marriages, i.e., prolonged cohabitation of men and women not registered by the church (among the nobility and intellectuals this meant "free love"), and marriages registered abroad became somewhat more widespread [Veremenko 2007: 49-50].

Between 1780 and 1850 the modal age of brides grew from 15-16 to 18-20 years, and of bridegrooms - from 16-18 to 20-21 years [Mironov 2014: v.1: 564]. In the post-reform period, the mean age at marriage stabilized ${ }^{1}$ [Tolts 1977: 139], but there was a slight upward trend: from 1867

\footnotetext{
${ }^{1}$ The mean age of all Russian brides who entered a first marriage in 1867-1910 was 21.4 years, of grooms - 24.2 years.
} 
to 1910 , this age increased by about half a year. However, the mean age of married men in urban areas decreased as a result of the immense migration of peasants who, as was customary in the countryside, married early (Table 2).

Table 2. Mean age at marriage of the urban and rural population of European Russia in 1867 and 1910, in years

\begin{tabular}{l|c|c|c|c}
\hline \multirow{2}{*}{ Population } & \multicolumn{2}{|c|}{ Men } & \multicolumn{2}{c}{ Women } \\
\cline { 2 - 5 } & 1867 & 1910 & 1867 & 21.6 \\
\hline Rural & 24.3 & 24.8 & 21.3 & 23.7 \\
Urban & 29.2 & 27.4 & 23.6 & 21.9 \\
Total & 24.8 & 25.2 & 21.5 & \\
\hline
\end{tabular}

Sources: [Population Movement... 1872: 40-407, 412-415; Population Movement... 1916: 88-89].

The relative stability of the mean age concealed the changes in the age structure of married couples: the share of those married before age 21 and after age 30 decreased, and of those between 21 and 30 increased (Table 3).

Table 3. Distribution by age group of those marrying in European Russia in 1867-1910, \%

\begin{tabular}{l|c|c|c|c|c|c}
\hline \multirow{2}{*}{ Years } & \multicolumn{7}{c}{ Age of grooms, years } \\
\cline { 2 - 7 } & 20 and under & $21-25$ & $25-30$ & $30-40$ & $40-50$ & 51 and over \\
\hline $1867-1871$ & 37.8 & 31.0 & 10.9 & 12.6 & 5.9 & 1.8 \\
$1872-1876$ & 37.7 & 30.7 & 13.0 & 11.5 & 5.2 & 1.9 \\
$1877-1881$ & 37.2 & 29.7 & 15.9 & 10.5 & 4.6 & 2.1 \\
$1890-1894$ & 31.2 & 33.9 & 19.1 & 9.8 & 4.1 & 1.9 \\
$1895-1898$ & 30.8 & 35.6 & 19.1 & 9.1 & 3.5 & 1.8 \\
1910. & 30.8 & 36.2 & 18.8 & 8.9 & 3.5 & 1.8 \\
$1867-1871$ & 57.3 & 26.3 & Age of brides, years & & \\
$1872-1876$ & 57.7 & 26.8 & 7.1 & 6.7 & 2.2 & 0.4 \\
$1877-1881$ & 59.0 & 27.0 & 7.0 & 5.9 & 2.2 & 0.4 \\
$1890-1894$ & 55.3 & 30.4 & 7.3 & 5.2 & 2.0 & 0.1 \\
$1895-1898$ & 54.7 & 31.7 & 7.1 & 4.8 & 1.8 & 0.4 \\
1910. & 54.5 & 31.0 & 7.3 & 4.5 & 1.6 & 0.4 \\
\hline
\end{tabular}

Sources: [Rashin 1956: 174-175; Sbornik svedeniy po Rossii... 1887: 36-37].

The percentage of persons who refrained from marriage increased, but only slightly. Until the middle of the $19^{\text {th }}$ century, only persons with serious disabilities (about $3 \%$ of the population) remained unmarried. At the turn of the nineteenth and twentieth centuries, the proportion of people who had not married by the end of their fertile years rose to $4 \%$ in the countryside and to $11 \%$ in the city (Table 4).

At the same time, the proportion of persons who did not remarry after widowhood increased to about $15 \%$ in the city and $9 \%$ in the village. As a result, the average length of marriages dropped - to about 20 years for townspeople and 25 years for peasants [Vishnevsky 1977: 114-120; Tolts 1977: 138-153]. Changes in the marital model began in the city in the first half of the $19^{\text {th }}$ century and spread to the countryside in the second half of the century, as is clearly visible from the data in Table 5. In 1910, the changes in the age structure of marriage affected mainly large cities, then small towns, and finally rural areas. 
Table 4. The proportion of people widowed and never married among the urban and rural population of European Russia in 1897

\begin{tabular}{l|c|c|c|c|c|r|r|r}
\hline \multirow{2}{*}{ Age, years } & \multicolumn{4}{|c|}{ Never married, \% } & \multicolumn{4}{c}{ Widowed, \% } \\
\cline { 2 - 9 } & \multicolumn{3}{c}{ Men } & \multicolumn{2}{c|}{ Women } & \multicolumn{2}{c}{ Men } & \multicolumn{2}{c}{ Women } \\
\cline { 2 - 9 } & urban & rural & urban & rural & urban & rural & urban & rural \\
\hline $15-19$ & 98 & 95 & 91 & 87 & - & - & - & - \\
$20-29$ & 60 & 35 & 38 & 20 & 1 & 1 & 4 & 1 \\
$30-39$ & 18 & 6 & 16 & 6 & 2 & 1 & 12 & 5 \\
$40-49$ & 11 & 3 & 12 & 4 & 5 & 4 & 26 & 14 \\
$50-59$ & - & - & - & - & 11 & 11 & 45 & 29 \\
15 and older & 42 & 28 & 30 & 21 & 4 & 6 & 18 & 13 \\
\hline
\end{tabular}

Sources: [Tolts 1977: 140, 149; Novoselsky 1916a:28].

Table 5. Distribution by age group of those marrying in urban and rural areas of European Russia in 1910

\begin{tabular}{l|c|c|c|c|c|c}
\hline \multirow{2}{*}{ Where marriage took place } & \multicolumn{9}{c}{ Age, years } \\
\cline { 2 - 7 } & $<20$ & $21-25$ & $26-30$ & $31-40$ & $41-50$ & $51+$ \\
\hline In main cities & 11.5 & 36.4 & 29.0 & 16.0 & 4.8 & 2.3 \\
In other cities & 14.4 & 40.1 & 27.1 & 12.1 & 4.0 & 2.3 \\
In rural areas & 33.3 & 36.0 & 17.5 & 8.1 & 3.4 & 1.7 \\
Total & 30.8 & 36.2 & 18.8 & 8.9 & 3.5 & 1.8 \\
& & Women & & & & \\
In main cities & 35.5 & 35.1 & 14.3 & 10.6 & 3.7 & 0.8 \\
In other cities & 43.0 & 37.4 & 10.8 & 6.0 & 2.1 & 0.7 \\
In rural areas & 56.7 & 30.2 & 6.7 & 4.1 & 1.7 & 0.6 \\
Total & 54.5 & 31.0 & 7.3 & 4.7 & 1.9 & 0.6 \\
\hline
\end{tabular}

Source: [Population Movement ... 1916: 88-89].

These changes in the marriage model were initiated by the educated segments of the population, primarily the nobility, who were concentrated in urban areas. Data on the family status of the most important estates in five gubernias (Grodno, Kaluga, Perm, Simbirsk and Yaroslavl) in the 1850s and 1897 well reflect this (Table 6).

Given that educated people, as well as many foreigners, were concentrated in the capital of the empire, Petersburg, changes in the marriage model were particularly noticeable there. By 1864 the share of unmarried men and women in the capital had reached 35\%. The mean age at first marriage was 30.5 years for men, 25.5 years for women. The seasonal fluctuations of marriage decreased significantly. [St. Petersburg 1868: vol.1: 104, 134, 138, 144]. At the beginning of the $20^{\text {th }}$ century the number of divorced persons exceeded a hundred for the first time, representing $0.18 \%$ of the entire population of the city [Statisticheskiy ezhegodnik S.-Peterburga ... 1905: 17], and thousands of people married in civil rather than church ceremonies. Guardianship surveys of 1915-1916 among families of the capital's lower military ranks revealed that about $10 \%$ of families had unmarried partners, which caused a sensation [Bulgakova 2008; 2009]. Of course, this was wartime, when a huge number of soldiers were concentrated in Petrograd. However, such a large number of unregistered common-law marriages could not have occurred had the ground not been already prepared. 
Table 6. Marital status of the population of marriageable age in European Russia by estate in the 1850 s and in $1897, \%$

\begin{tabular}{|c|c|c|c|c|c|c|c|c|}
\hline \multirow[t]{2}{*}{ Marital status } & \multicolumn{2}{|c|}{$\begin{array}{c}\text { Merchants, lower } \\
\text { middle class }\end{array}$} & \multicolumn{2}{|c|}{ Peasants } & \multicolumn{2}{|c|}{ Nobles } & \multicolumn{2}{|c|}{ Clergy } \\
\hline & men & women & men & women & men & women & men & women \\
\hline \multicolumn{9}{|c|}{ 1850s, for five gubernias } \\
\hline $\begin{array}{l}\text { Under } \\
\text { marriageable age }\end{array}$ & 42 & 33 & 44 & 40 & - & - & 50 & 39 \\
\hline Never married & 15 & 21 & 7 & 12 & - & - & 7 & 13 \\
\hline Married & 38 & 32 & 44 & 40 & - & 一 & 37 & 35 \\
\hline Widowed & 5 & 14 & 5 & 8 & - & 一 & 6 & 13 \\
\hline \multicolumn{9}{|c|}{ 1897, for five gubernias } \\
\hline $\begin{array}{l}\text { Under } \\
\text { marriageable age }\end{array}$ & 34 & 33 & 47 & 41 & - & - & - & - \\
\hline Never married & 23 & 19 & 8 & 12 & - & - & - & - \\
\hline Married & 40 & 34 & 41 & 38 & - & - & - & - \\
\hline Widowed & 3 & 14 & 4 & 9 & - & - & - & - \\
\hline Divorced & 0.1 & 0.1 & 0.07 & 0.05 & - & 一 & - & - \\
\hline \multicolumn{9}{|c|}{ 1897, European Russia } \\
\hline $\begin{array}{l}\text { Under } \\
\text { marriageable age }\end{array}$ & 43 & 39 & 45 & 40 & 36 & 30 & 40 & 32 \\
\hline Never married & 17 & 16 & 11 & 12 & 26 & 24 & 19 & 27 \\
\hline Married & 37 & 35 & 40 & 40 & 34 & 32 & 34 & 29 \\
\hline Widowed & 3 & 10 & 4 & 8 & 4 & 14 & 7 & 12 \\
\hline Divorced & 0.1 & 0.3 & 0.01 & 0.05 & 0.2 & 0.2 & 0.04 & 0.04 \\
\hline
\end{tabular}

Sources: [Lukanin 1878: 206; Trubnikov, 1858: 417; O sostave i dvizhenii naseleniya... 1861: 90; Bobrovsky 1863: 536-540; Prostky 1864: 330; Obshchiy svod ... 1905: vol.2: 198-207, 216-219, 224-225].

Transformations in the objective conditions of life were not the only source of changes in the marital model; there were changed attitudes toward marriage as well. The idea of lifelong marriage began to erode; if a partner abused his power, was unfaithful, left for a very long time or did not perform his matrimonial duties, he could now be replaced through divorce. To a lesser extent, these changes also affected peasant families and the urban underclasses, i.e., about $90 \%$ of the country's population.

Table 7. The number of marriages from the 1800s through the 1960s in Russia and a number of other countries, per 1000 people

\begin{tabular}{l|c|r|r|r|r|r|r|r}
\hline \multirow{2}{*}{ Country } & \multicolumn{8}{c}{ Years } \\
\cline { 2 - 9 } & $1800 \mathrm{~s}$ & $1850 \mathrm{~s}$ & $1880 \mathrm{~s}$ & $1900 \mathrm{~s}$ & $1920 \mathrm{~s}$ & $1930 \mathrm{~s}$ & $1950 \mathrm{~s}$ & $1960 \mathrm{~s}$ \\
\hline Russia & 9.9 & 10.3 & 9.2 & 8.5 & 9.9 & 6.3 & 11.9 & 10.8 \\
Austro-Hungary* & 8.1 & 8.0 & 7.8 & 7.8 & 9.2 & 8.6 & 8.3 & 8.0 \\
England & - & 8.5 & 7.5 & 7.0 & 8.0 & 8.5 & 7.9 & 7.8 \\
USA & - & 9.6 & 8.7 & 10.5 & 10.5 & 9.8 & 9.5 & 9.3 \\
Germany & 8.2 & 8.0 & 7.4 & 8.1 & 9.7 & 9.4 & 9.3 & 8.5 \\
France & 7.6 & 8.0 & 7.4 & 7.8 & 9.7 & 7.1 & 7.3 & 7.1 \\
Japan & - & - & 8.2 & 8.8 & 8.5 & 8.0 & 8.4 & 9.7 \\
\hline
\end{tabular}

Source: [Mironov 2015: vol.3: 753-756].

Note: * Austria since 1918.

Changes in the marriage model led to a decrease in the general level of nuptiality in the country. And yet, Russia had the highest marriage rate among the developed European countries and the United States up to the beginning of the $20^{\text {th }}$ century. Only in the 1900 s did the United 
States, after the huge emigration of the adult population from Europe, take the lead, a lead it would retain for the next 40 years (Table 7).

The Russian model of nuptiality of the $18^{\text {th }}$ to the first half of the $19^{\text {th }}$ century differed from that in Western Europe, which was characterized by late marriage (brides over age 25 and grooms over 27), and where a significant proportion of persons never married at all (at least 9-10\%, and in some cases more than 15\%). The shifts in the post-reform period somewhat reduced the differences, but a significant gap still remained at the beginning of the twentieth century (Tables $8,9)$.

Table 8. Proportion of never married men and women in some European countries at the turn of the $20^{\text {th }}$ century, \%

\begin{tabular}{|c|c|c|c|c|}
\hline \multirow{3}{*}{ Country } & \multicolumn{4}{|c|}{ Age, years } \\
\hline & \multicolumn{2}{|c|}{ women } & \multicolumn{2}{|c|}{ men } \\
\hline & $20-24$ & $45-49$ & $20-24$ & $45-49$ \\
\hline Ireland & 86 & 17 & 96 & 20 \\
\hline Sweden & 80 & 19 & 92 & 13 \\
\hline Great Britain & 73 & 15 & 83 & 12 \\
\hline Germany & 71 & 10 & 91 & 9 \\
\hline Finland & 68 & 15 & 84 & 14 \\
\hline Italy & 60 & 11 & 86 & 11 \\
\hline France & 58 & 12 & 90 & 11 \\
\hline Spain* & 81 & 34 & 55 & 10 \\
\hline Greece & 44 & 4 & 82 & 9 \\
\hline European Russia** & 35 & 5 & 54 & 4 \\
\hline Bulgaria & 24 & 1 & 58 & 3 \\
\hline Romania & 20 & 3 & 67 & 5 \\
\hline Serbia & 16 & 1 & 50 & 3 \\
\hline
\end{tabular}

* Age groups for Spain: 21-25 years; 46-50 years. ** According to calculations by M. Tolts.

Sources: [Hajnal 1965: 102-103; Tolts 1977: 139].

Table 9. Proportion of never married persons aged 45-49 in some countries of the world at the turn of the $20^{\text {th }}$ century, $\%$

\begin{tabular}{lc|c|l|r|r}
\hline Country, year & Women & Men & Country, year & Women & Men \\
\hline Sweden, 1900 & 19.0 & 13.0 & Australia, 1901 & 9.3 & 22.4 \\
Belgium, 1900 & 17.1 & 16.1 & USA, 1900 & 8.6 & 12.0 \\
Switzerland, 1900 & 17.0 & 16.0 & Czech Republic, 1910 & 8.5 & 6.2 \\
Netherlands, 1900 & 14.0 & 13.0 & Poland, 1900 & 7.8 & 6.1 \\
England and Wales, 1901 & 13.4 & 11.0 & European Russia, 1897 & 5.0 & 4.0 \\
Austria, 1900 & 13.0 & 11.0 & Greece, 1907 & 4.0 & 9.0 \\
Canada, 1911 & 12.0 & 15.1 & Hungry, 1900 & 4.0 & 5.0 \\
France, 1901-1905 & 11.2 & 10.4 & Romania, 1899 & 3.0 & 5.0 \\
Italy, 1901 & 10.9 & 10.9 & Japan, 1920 & 1.9 & 2.3 \\
Spain, 1900 & 10.2 & 6.4 & Bulgaria, 1900 & 1.0 & 3.0 \\
Germany, 1900 & 10.1 & 8.2 & Serbia, 1900 & 1.0 & 3.0 \\
\hline
\end{tabular}

Source: [Patterns of first marriage... 1990: 7-18].

Both in the village and in the city the family organization of the population was changing. The available data on the peasant family structure show that through the $16^{\text {th }}$ and into the first half of the $19^{\text {th }}$ century the small and the extended family coexisted peacefully. Their ratio, however, changed, which was explained by changes in the tax system and the prosperity of the population, economic conditions, social and economic crises, the policy of landlords towards their peasants, 
and colonization. Until the middle of the $19^{\text {th }}$ century an extended family often grew into a large family and, in rare cases, into an ancestral family that combined many married couples and up to 100 people. Even in the 1850s there were many large families in each province, numbering 20-30 or more people. Their share was not large (0.3-1.6\%), but there were thousands of them. All this shows that even in the middle of the $19^{\text {th }}$ century the large family had not yet become obsolete. During the post-reform period, the small family became noticeably more common in all regions of the countryside than it had been in the middle of the nineteenth century, and by 1897 it was numerically dominant among the peasantry of European Russia, although only slightly. Socioeconomic factors played a significant role in preserving the tradition of the extended family, including the repartitioning of communes, serfdom, legal restrictions on the development of private ownership of land, the absence of primogeniture, the provision of land and other natural resources, the form of rent, climate, the nature of economic activity, the degree of the development of the labor market, and others.

Townspeople in the period of the empire preferred small families. However, until the middle of the $19^{\text {th }}$ century more than half of the urban population lived in an extended family for a certain period of their lives. In different social groups and in different regions the process of nuclearization occurred inconsistently, but by the beginning of the twentieth century the small family had become victorious. The city was ahead of the country by about 50 years, that is, two generations, in the eradication of archaic forms of family organization: the typology of families observed in the cities in the middle of the $19^{\text {th }}$ century came to the countryside only at the century's turn.

The process of full and final nuclearization of family organization was completed only in the $20^{\text {th }}$ century. The share of extended families in the family structure in 1994 was only $3.6 \%$. Furthermore, as a rule they persisted not because of a desire of parents and children to continue living together, but due to necessity, to the lack of availability of separate housing for young people.

In the post-reform period, all social classes also experienced changes in intra-family relations. The nobility and the intelligentsia pioneered the transition from patriarchal-authoritarian to egalitarian families and from patriarchal to democratic relations within the family in the last third of the $19^{\text {th }}$ and early $20^{\text {th }}$ centuries. However, the patriarchal-authoritarian basis of intrafamily relations was not seriously undermined either among the peasantry or the urban lower classes, and it was largely preserved until 1917. This is evidenced by the fact that, even in the Russian village of the 1920s, traditional views on the family and women remained very strong [Fenomenov 1925: 98-106; Yakovlev 1923; 1924; Bridger 1992: 271-293; Farnsworth 1992: $167-$ 188]. Progress was manifested in the mitigation of violence against the weaker members of the family and in the establishment of a certain amount of social and legal oversight in protecting the interests of women and children. Authoritarianism within the family was, to a greater or lesser degree, placed within the framework of the law. Until the middle of the $19^{\text {th }}$ century marriages were, as a rule, concluded by direct instruction of the parents, by means of matchmaking, through an engagement and a wedding that took family interests into account. In the last third of the $19^{\text {th }}$ to the early $20^{\text {th }}$ century, young people began to participate in the choice of a spouse, guided by inclination and other personal considerations. At the same time, the goals of encounters with the opposite sex expanded: young people no longer sought only a spouse, but also a source of 
entertainment, emotional contact, pleasure, etc. Powerful remnants of serfdom, persistent patriarchy within the family, and the poorly developed feminist movement in Russia prevented the completion of this process even among the elite of Russian society, if by this we mean the bulk of the families of the privileged strata.

Many researchers, both past and present, see the changes in the family way of life in late imperial Russia as a crisis of the institution of the family, and at the same time a sign of the general social crisis of Russian society. It is difficult to agree with this. It is impossible to consider such progressive changes as a reduction of marriage and birth rates from an unreasonable height to a "normal" level as a crisis. The same is true of an increase in the age of marriage, the nuclearization, democratization and humanization of intra-family relations, improvement of the status of women and children, a rise in the number of divorces and separations, an increase in the number of common-law marriages and conflicts between spouses and "fathers and children", an expansion of the use of contraception and abortion, a simplification of the legalization of illegitimate children and the adoption of legal children, and the institution of regulatory supervision by society and the courts over the interests of women and children. For example, the dissolution of 3,791 out of 1,053,000 marriages contracted in 1913 [Statisticheskii ezhegodnik ... 1916: 2] cannot be considered a crisis of the family, even if the number of divorces had increased by 46 times compared with 1861 . The changes listed do not, in fact, testify to a crisis in the institution of the family, but to its development in the direction of modernization. One can only regret that these changes affected mainly the educated part of society and did not spread far enough. These changes themselves were conditioned by modern processes: secularization, democratization, industrialization, urbanization, the growth of literacy and the spread of liberal ideas in society. Thanks to the rapid development of the mass media, new family practices became known to the public and became the subject of sharp public disputes between people who held different ideological orientations [Nikologorsky 2012: 28-32]. And it is worth recalling that modernization is always, everywhere and in all spheres of life a painful process.

\section{FERTILITY AND MORTALITY}

The decline in fertility began in the second third of the $19^{\text {th }}$ century among the nobility, officials, the upper stratum of the urban population, and also among peasant serfs of landowners. In the second half of the $19^{\text {th }}$ century it gradually encompassed all other groups of the population and all regions of European Russia. As a result, between 1841 and 1920 the total birth rate in generational cohorts of "mothers" compared with the birth rate in cohorts of "daughters" decreased by 2.3 times, according to an estimate by S.V. Zakharov (Table 10).

As in the case with nuptiality, the decline in fertility was influenced by economic, cultural and psychological factors, among which the increase in population density and the corresponding decrease in natural resources per capita in the village in the second third of the $19^{\text {th }}$ century should be emphasized, as well as the changing cultural standards among the educated and urban classes. It is important to underline the fact that the decline in fertility did not occur spontaneously, but consciously, as a result of the decrease in marriage and of the use of birth control starting in the second third of the $19^{\text {th }}$ century (more on this below). In Russia, this began at a higher level and later than in most developed countries - 30-40 years later, on average, than in most European 
countries, and nearly a century later than in France. However, over time the differences decreased (Table 11).

Table 10. Total fertility of real generations in Russia in 1841-1920

\begin{tabular}{c|c|c|c|c}
\hline \multicolumn{2}{c|}{ Year of birth } & \multicolumn{2}{|c|}{ Total fertility } & $\begin{array}{c}\text { Ratio of fertility in cohorts of } \\
\text { "daughters" to that of } \\
\text { "mothers" }\end{array}$ \\
\hline $\begin{array}{c}\text { Cohort o } \\
\text { "mothers" }\end{array}$ & $\begin{array}{c}\text { Cohort of } \\
\text { "daughters" }\end{array}$ & $\begin{array}{c}\text { Cohort of } \\
\text { "mothers" }\end{array}$ & $\begin{array}{c}\text { Cohort of } \\
\text { "daughters" }\end{array}$ & 1.017 \\
\hline $1841-1845$ & $1871-1875$ & 6.84 & 6.96 & 0.993 \\
$1846-1850$ & $1876-1880$ & 6.9 & 6.85 & 0.876 \\
$1851-1855$ & $1881-1885$ & 7.08 & 6.2 & 0.772 \\
$1856-1860$ & $1886-1890$ & 7.11 & 5.49 & 0.772 \\
$1861-1865$ & $1891-1895$ & 7.12 & 5.5 & 0.726 \\
$1866-1870$ & $1896-1900$ & 7.2 & 5.23 & 0.659 \\
$1871-1875$ & $1901-1905$ & 6.96 & 4.59 & 0.534 \\
$1876-1880$ & $1906-1910$ & 6.85 & 3.66 & 0.455 \\
$1881-1885$ & $1911-1915$ & 6.2 & 2.82 & 0.448 \\
$1886-1890$ & $1916-1920$ & 5.49 & 2.46 & \\
\hline
\end{tabular}

Source: [Zakharov 2002: 19-26; 2003: 3-12].

Table 11. Total fertility rate from the 1800s through the 1960s in Russia and a number of other countries, per 1000 people

\begin{tabular}{l|r|r|r|r|r|r|r|c}
\hline \multirow{2}{*}{ Country } & \multicolumn{8}{c}{ Years } \\
\cline { 2 - 9 } & $1800 \mathrm{~s}$ & $1850 \mathrm{~s}$ & $1880 \mathrm{~s}$ & $1900 \mathrm{~s}$ & $1920 \mathrm{~s}$ & $1930 \mathrm{~s}$ & $1950 \mathrm{~s}$ & $1960 \mathrm{~s}$ \\
\hline Russia & 50.3 & 51.5 & 50.3 & 47.2 & 44.0 & 34.6 & 25.9 & 20.0 \\
Austro-Hungary* & 39.5 & 37.8 & 38.0 & 34.9 & 20.5 & 14.9 & 15.9 & 17.9 \\
England & - & 34.1 & 32.9 & 28.7 & 19.3 & 15.1 & 15.7 & 17.6 \\
USA & 57.7 & 45.3 & 39.8 & 31.2 & 25.0 & 19.2 & 24.8 & 20.3 \\
Germany & 38.3 & 35.4 & 37.0 & 33.6 & 21.1 & 17.8 & 16.1 & 17.3 \\
France & 32.0 & 26.4 & 24.2 & 20.7 & 19.1 & 15.9 & 18.0 & 17.5 \\
Japan & - & - & 26.9 & 32.1 & 34.1 & 30.2 & 19.8 & 17.7 \\
\hline
\end{tabular}

* Austria since 1918.

Source: [Mironov 2015: vol. 3: 753-756].

Throughout the $18^{\text {th }}$ to the early $20^{\text {th }}$ century mortality among the Orthodox population of Russia was at a very high level both in the city and the countryside, among the common people and among the privileged members of society. In the $18^{\text {th }}$ century, the overall mortality rate in the city ranged between 40 and 60, and in the village, between 30 and 40 per 1000 people. In the first half of the $19^{\text {th }}$ century, the fluctuations in mortality evened out somewhat over the years, but the average level remained high, as before: in the city about 49, in the village 35 per 1000 [Mironov 1990: table 2]. Starting in the 1860s, mortality began to decline gradually: in the city, the overall mortality rate between 1851-1859 and 1909-1913 fell from 53 to 27, in the village - from 39 to 32 per 1,000 [Novoselsky 1916a: 45-46; 1916b: 180-187]. The decline in mortality was widespread, but was more intense in the city than in the countryside, more significant in large cities than in small ones, more rapid among the privileged classes than the lower classes, and began earlier in the western provinces than in the central and eastern ones. The overall mortality rate was reduced mainly due to a drop in infant mortality [Avdeev 2008].

The level of both rates was much higher in Russia than in most developed countries: in the 1900s, Russia lagged a century behind in these indicators. In terms of overall mortality, a leveling 
out occurred in the 1950s (Table 12), while for infant mortality the differences decreased, but parity has still not been achieved (Table 13).

Table 12. Total mortality rate from the 1800s through the 1960s in Russia and a number of other countries, per 1000 people

\begin{tabular}{l|c|c|c|c|c|c|r|r}
\hline \multirow{2}{*}{ Country } & \multicolumn{8}{c}{ Years } \\
\cline { 2 - 9 } & $1800 \mathrm{~s}$ & $1850 \mathrm{~s}$ & $1880 \mathrm{~s}$ & $1900 \mathrm{~s}$ & $1920 \mathrm{~s}$ & $1930 \mathrm{~s}$ & $1950 \mathrm{~s}$ & $1960 \mathrm{~s}$ \\
\hline Russia & 36.8 & 39.8 & 35.4 & 30.2 & 22.9 & 18.0 & 8.5 & 7.4 \\
Austro-Hungary* & 28.2 & 32.1 & 29.5 & 23.7 & 15.7 & 13.7 & 12.4 & 12.8 \\
England & - & 22.1 & 19.2 & 16.9 & 12.2 & 12.0 & 11.6 & 11.7 \\
USA & - & 19.5 & 18.4 & 15.8 & 11.9 & 11.0 & 9.5 & 9.5 \\
Germany & 25.2 & 26.6 & 25.3 & 19.3 & 12.9 & 11.4 & 11.0 & 11.6 \\
France & 28.0 & 23.9 & 22.1 & 19.8 & 17.2 & 15.5 & 12.2 & 11.1 \\
Japan & - & - & 19.6 & 20.9 & 20.6 & 17.6 & 8.2 & 7.0 \\
\hline
\end{tabular}

* Austria since 1918.

Source: [Mironov 2015: vol.3: 753-756].

Table 13. Infant mortality rate from the 1800s through the 1960s in Russia and a number of other countries, per 1000 births

\begin{tabular}{l|r|r|r|r|r|r|r|r}
\hline \multirow{2}{*}{ Country } & \multicolumn{8}{c}{ Years } \\
\cline { 2 - 9 } & $1800 \mathrm{~s}$ & $1850 \mathrm{~s}$ & $1880 \mathrm{~s}$ & $1900 \mathrm{~s}$ & $1920 \mathrm{~s}$ & $1930 \mathrm{~s}$ & $1950 \mathrm{~s}$ & $1960 \mathrm{~s}$ \\
\hline Russia & - & 272.0 & 268.0 & 250.0 & 206.0 & 182.0 & 60.9 & 29.0 \\
Austro-Hungary* & 188.0 & 250.0 & 249.0 & 213.0 & 129.0 & 93.6 & 49.0 & 29.7 \\
England & - & 155.0 & 142.0 & 132.0 & 73.8 & 59.0 & 26.0 & 19.8 \\
USA & - & 127.0 & 160.0 & 96.5 & 73.1 & 56.8 & 27.3 & 24.0 \\
Germany & 294.0 & 172.0 & 167.0 & 193.0 & 112.0 & 65.1 & 44.0 & 26.4 \\
France & 185.0 & 172.0 & 167.0 & 137.0 & 101.0 & 75.0 & 40.0 & 23.3 \\
Japan & - & - & - & - & 148.0 & 114.0 & 42.0 & 19.4 \\
\hline
\end{tabular}

* Austria since 1918.

Source: [Mironov 2015: vol.3: 753-756].

The decline in mortality in the 1860s was due to an increase in the living standards of the population and an improved diet [Mironov, 2012: 697-701], as well as to the growth of the cultural level of the population and the expansion of free medical care. From 1850-1913 the literacy rate for those over the age of 9 rose from 15 to $40 \%$ [Mironov 1991: 82]. In 1837, there were 6,800 doctors in Russia (not including dentists), in 1846 - 8,700, in 1880 - 13,500, and in $1913-28,100$ [Khanykov 1851: 31-32; Mironov 1991: 144]. The number of medical stations, where peasants received free medical assistance, increased between 1870 and 1913 from 530 to 2,970, or 5.6 times [Novoselsky 1916b: 184]. But in this respect Russia still lagged far behind the advanced European countries (Table 14).

In parallel with the drop in mortality, there was a rise in life expectancy. In the years 18381850, newborn boys of the Orthodox faith could expect to live approximately 25 years, girls -27 ; in 1904-1913 the corresponding figures were 32.4 and 34.5 years [Vosproizvodstvo naseleniya SSSR... 1983: 61]. In the 1900s, Russia was about 100 years behind the leading countries; in the 1950s, the gap was overcome (Table 15). 
Table 14. Features of the availability of medical care in Russia and some European countries at the end of the $19^{\text {th }}$ century

\begin{tabular}{lrr|r|r|r}
\hline \multirow{2}{*}{ Country } & \multicolumn{2}{|c|}{ Number of doctors } & \multicolumn{3}{c}{ Per doctor } \\
\cline { 2 - 6 } & \multicolumn{1}{|c|}{ Total } & Per 1 million people & Number of people & Territory, $\mathrm{km}^{2}$ & Radius, km \\
\hline European Russia & 13475 & 155 & 6450 & 1352 & 21 \\
Norway & 502 & 275 & 3630 & 641 & 14 \\
Austria & 10690 & 275 & 3630 & 28 & 3 \\
Italy & 8580 & 280 & 3570 & 35 & 3 \\
Spain & 5200 & 305 & 3280 & 99 & 6 \\
Germany & 16270 & 355 & 2820 & 33 & 3 \\
France & 14380 & 380 & 2630 & 37 & 3 \\
Belgium & 2160 & 390 & 2540 & 16 & 2 \\
Netherlands & 1860 & 410 & 2440 & 18 & 2 \\
Great Britain & 22105 & 578 & 1730 & 10 & 2 \\
\hline
\end{tabular}

Source: [Khlopin, Erisman 1899: 225].

Table 15. Life expectancy at birth from the 1800s through the 1960s in Russia and a number of other countries, in years

\begin{tabular}{|c|c|c|c|c|c|c|c|c|}
\hline \multirow{2}{*}{ Country } & \multicolumn{8}{|c|}{ Years } \\
\hline & $1800 \mathrm{~s}$ & $1850 \mathrm{~s}$ & $1880 \mathrm{~s}$ & $1900 \mathrm{~s}$ & $1920 \mathrm{~s}$ & $1930 \mathrm{~s}$ & $1950 \mathrm{~s}$ & $1960 \mathrm{~s}$ \\
\hline Russia & - & 25.8 & 30.0 & 33.5 & 44.4 & 46.9 & 68.1 & 69.1 \\
\hline Austro-Hungary* & - & - & 一 & 40.1 & 一 & 57.0 & 64.5 & 69.8 \\
\hline England & 一 & 42.4 & 45.5 & 53.4 & 57.6 & 60.8 & 70.3 & 71.0 \\
\hline USA & - & 41.0 & 43.5 & 50.6 & 58.7 & 63.7 & 69.9 & 71.0 \\
\hline Germany & - & - & 46.6 & 49.1 & 57.4 & 61.4 & 66.5 & 70.5 \\
\hline France & 39.6 & 39.8 & 47.0 & 50.5 & 54.2 & 58.8 & 68.1 & 71.4 \\
\hline Japan & - & - & 43.6 & 44.5 & 44.2 & 48.3 & 66.2 & 71.7 \\
\hline
\end{tabular}

* Austria since 1918.

Source: [Mironov 2015: vol.3: 753-756].

In the years 1896-1897 the total fertility of the Russian population was $54 \%$ of the physiological maximum (which is taken to be the marital fertility of the Hutterites, members of an American religious sect distinguished by good health and a total lack of birth control), and marital fertility was 76\% [Vishnevsky 1977: 131].

\section{INNOVATIONS AND DEVIATIONS IN DEMOGRAPHIC BEHAVIOR}

Deviations in demographic behavior can be seen as innovations at the individual level directed against traditional attitudes and dominant practices. The scale of deviations shows the number of people who are ready and inclined to change patterns of traditional behavior. These include premarital sex, extramarital affairs and illegitimate children, divorce, suicide, abortion and infanticide, and contraception.

\section{Premarital and extramarital sex}

For the entire period under investigation, the desire to prevent pregnancy or to get rid of an unwanted child was characteristic of those women who had extramarital sex, since giving birth outside of marriage was considered tremendously disgraceful both for the woman and her relatives. Very often mothers of illegitimate children were the wives of soldiers whose husbands had entered 
the $\operatorname{army}^{2}$ [Shcherbinin 2004: 95-132]. How many such women were there? Data on the number of women aged 16-49 with illegitimate children among the entire female population of reproductive age, which was about $1 \%$, can provide us with an approximate answer to this question. Judging by the Yaroslavl gubernia of 1850, which occupied a middle position among the 50 provinces of Russia in terms of the percentage of illegitimate children among all newborns, we can assume that by the mid $-19^{\text {th }}$ century there were some 260,000 women with illegitimate children [Istoriko-statisticheskie tablitsy ... 1901: 92]. They were distributed unevenly between the city and the village. In the country as a whole between 1859 and 1863 about $26 \%$ of illegitimate children were born in cities, and 74\% in rural areas, while in 1910 the corresponding figures were 41 and 59\% [Military Statistical Collection 1871: 66-68; The movement of the population ... 1916: 51]. The distribution of illegitimate children between the city and the village depended on the existence of large cities in the province. For example, in the 1850 s about $67 \%$ of all the illegitimate children in the Moscow gubernia were born in the city of Moscow. In the Yaroslavl gubernia, which had well-developed, if less significant, cities than Moscow, 55\% of all illegitimate children of the province were concentrated in cities, and in the Poltava gubernia, which had no large cities, the share of illegitimate children in cities was only $25 \%$, with the remaining $75 \%$ being born in the countryside $^{3}$ [Istoriko-statisticheskie tablitsy ... 1901: 92]. As we can see, even before emancipation there were many women seeking to get rid of an unwanted child both in the city and in the countryside; after emancipation, their numbers became even greater.

The proportion of illegitimate children registered by Orthodox priests among the total number of newborns in the late 18th and first half of the $19^{\text {th }}$ century ranged from $2 \%$ in the Kiev gubernia to $7 \%$ in the Moscow gubernia, or an average of 3.3\% in European Russia ${ }^{4}$, [Pamjatnaja knizhka ... 1861: 325; Pamjatnaja knizhka ... 1871: 137-140; Laptev 1861: 169, 180; Steel 1867: 205; Lipinsky 1868: 443]. This is somewhat less than in Western European countries, where the proportion of illegitimate children is estimated at 2\% in 1680 and 6\% in 1820 [Riddle 2001: 186]. In the post-reform period, the number of illegitimate children increased in absolute terms, but very slightly: in European Russia in 1859-1863 an average of 99,000 were registered annually [Military statistical collection 1871: 66-68], and in 1910 - 106,000 [Shcherbinin 2002: 142-146]. As a result of faster population growth, the percentage of registered illegitimate children among Orthodox Christians declined: in 1859-1863 it was 3.4\%, in $1870-3.0 \%$, in $1885-2.7 \%$, and in $1910-2.3 \% .^{6}$ So, it turns out that as modernization, urbanization and industrialization took place, there was a relative decrease in the number of illegitimate children among Orthodox women, while there was an increase among Old Believers, Catholics, Protestants and Jews. How can this paradox be explained? There are researchers who consider the available data on children born out of wedlock to be underestimated, due to the fact that over time the methods of record-keeping and the policy of foundling homes regarding the admission of illegitimate children changed [Ransel

\footnotetext{
${ }^{2}$ For a detailed analysis of the situation of illegitimate children, especially those belonging to soldiers' wives, see [Shcherbinin 2004].

3 RGO (Arkhiv Russkogo georgraficheskogo obshchestva), R. 22, op. 1., d. 3; dd. 1, 2; RGIA (Rossiiskii Gosudarstvennyi istoricheskii arkhiv), f. 796, op. 138, d. 2476 (Poltava Gubernia).

${ }^{4}$ RGIA, f. 796 (Chancery of the Synod), op. 63, d. 69; op. 445, dd. 423, 426; op. 95, d. 1189; op. 96, d. 1007; op. 104, d. 1364; op. 128, d. 2192; op. 2192; op. 131, d. 260; RGO R. 22, op. 1, d. 3 (Moscow); f. 16, d. 1 (Kiev).

${ }^{5}$ A significant portion of them were children of soldiers' wives.

${ }^{6}$ Since 1870, data on illegitimate children have been published in the annual "Dvizhenie naseleniya v Evropeyskoy Rossii ".
} 
1982: 11-27]. However, this cannot explain the reduction in the percentage of illegitimate children by a third, as this would mean an annual underestimation of several tens of thousands of newborns. The only satisfactory explanation, in my opinion, is that women who had extramarital relationships used contraceptive methods, and those who became pregnant out of wedlock got rid of the fetus by abortion or artificial miscarriage. Only this explanation can reconcile the seemingly contradictory facts observed in the post-reform period: 1) the number of unmarried women who had extramarital sex, according to the general opinion of contemporaries, increased; 2) the possibility of concealing the fact of the pregnancy and illegitimate birth from both relatives and priests increased; 3) among Old Believers, Catholics, Protestants, Jews and Muslims, unmarried women who gave birth to children were not condemned as severely as among the Orthodox, and their children were not discriminated against; 4) women had no reason to avoid registering an illegitimate child, first, because, according to religious beliefs, an unbaptized infant did not go to heaven, and secondly, because in 1891 the foundling homes to which children could be taken imposed restrictions on their admission, demanding certificates from the police or priests confirming that they were indeed illegitimate ${ }^{5}$ [Afinogenov 1903: 76]. If our assumption is correct, then the number of women who resorted to birth control or had an abortion over the course of any particular year exceeded 125,000 by 1910 . This figure was obtained as follows. In the years 18591863 the number of illegitimate children was 99,000, and their share among all newborns was $3.4 \%$. If women did not take measures against the birth of illegitimate children, then their number would have been 232,000 in 1910 (according to the percentage of illegitimate children in 18591863 among the total number of newborns in 1910). Meanwhile, in fact, 106,000 illegitimate children were registered.

An increase in the number of foundlings could serve as a good indicator of an increase in the number of unwanted children. But, although children were abandoned all over Russia throughout the entire period under investigation, there is no complete information on this. In 1867, official data on abandoned babies in European Russia were published for the first and only time, and put the number of foundlings at 2,254. As the compilers of the statistical compendium in which these data were published indicated, the information is incomplete [Population Movement ... 1872: IX, 10-11]. The increase in the number of persons prosecuted for abandoning babies attests to the growth of the phenomenon. In 1839, 47 men and 123 women were charged with abandoning babies, in 1873 the corresponding figures were 93 and 118, in 1892 - 206 and 805, in 1913 - 410 and 1759 [Svod statisticheskikh svedeniy... 1875, 1896,1916 ]. In reality, the number of abandoned babies was many times greater. For example, in 1867, according to extremely incomplete official data, the number of abandoned babies was 10 times greater than the number of persons prosecuted for abandoning them. The spread of infanticide can also serve as an indication that many women did not want children and tried to get rid of them [Uspensky, 1954: 110-114].

The two largest foundling homes in Russia, located in Moscow and St. Petersburg, provide a more adequate idea of the dynamics of the number of unwanted children. According to D. Ransel's estimates, in the years 1791-1800 both homes took in 3,342 babies per year, in 1841-

${ }^{5}$ Mothers of illegitimate children sought to hide the fact of birth not from priests, but from relatives and friends. To this end, they often changed the place of residence when the delivery approached: the peasant women left for the city, the townspeople moved to another apartment or to another city. This fact is noted in fiction; see, for example, Krestovsky's novel The Petersburg Slums. 
$1850-13,092$, in the years $1871-1880-20,169$, in the years $1881-1890-24,298$, in the years 1891-1900 - 17,785, in 1901-1910 - 19,218: that is, from the end of the 18th to the beginning of the $20^{\text {th }}$ century the number of foundlings increased 5.8 times, while the population of Russia increased 2.9 times [Ransel 1988: 303-308]. The number of babies taken in by foundling homes depended not only on the number of mothers who wanted to give them up, but also on the capacity and policies of the homes themselves. Therefore, for example, a decrease in the number of foundlings in 1891-1910 does not mean that the number of unwanted children had decreased, simply that foundling homes had introduced restrictions on receiving them, which immediately decreased the number of parents desiring to put their children there.

Since premarital sex was condemned and punished, until 1914 most people of both sexes, with the exception of the nobility and the intelligentsia, began having sex only after marriage. The mean age of all grooms and brides at the time of their first marriage can be considered the approximate age of their sexual debut. In the years 1867-1910 this age was 24.2 years for men, and 21.4 years for women [Tolts 1977: 139]. Some authors, relying on separate evidence, and not on statistics, argue that at the end of the $19^{\text {th }}$ century less than half of peasant men were virgins at the time of their first marriage (Kryukova 1992: 48; Tikhonov 1891: 136 $]$ ]. Others talk about the complete freedom of sexual relations between young men and women, and even about the survival of a such a primitive relic as svalnyi grekh (indiscriminate sin), when young people would gather, left alone by their elders, and would extinguish the light and engage in open relations with each other [Semenov 1996: 39-46; Balov 1898]. As a common custom this seems unlikely. If the vast majority of women retained their maidenhood until marriage, then how did men find partners, given that prostitution in the village was a rare phenomenon? If voluntary relations before marriage were common, then undoubtedly many illegitimate children would have been born, which is not recorded in the sources. One might grant the existence of such remnants among sectarians, or among the inhabitants of remote villages. For example, among the Old Believers, extramarital relations were allowed and the children born of them were recognized along with legitimate children [Bushnell 2011]. Observers from the city probably perceived a custom that existed, for example, in the villages of the Saratov gubernia as sexual freedom: "After a village gathering, the girls let the men spend the night. Lying down with their chosen man, they let themselves be kissed, but rarely went so far as to sin" [Minh 1890: 110].

However, among students in large cities sexual experience began earlier. According to a survey of two thousand Kharkov students in 1902, $73 \%$ made their sexual debut at the age of 17 20 [Favre 1910], and according to a similar survey of 2,150 Moscow students in 1904, 50\% of them engaged in sexual activity at the age of 14-17, including $22 \%$ at the age of 16 [Members 1907: 1072-1111]. Similar results were obtained from the so-called "student sex censuses" at the universities of Tomsk and Yuryev (Tartu). In 1908, V. Zhbankov conducted the world's first questionnaire survey of the sex life of 6,000 female students and teachers in Moscow, $80 \%$ of whom were under the age of 25 years. This was so novel and provocative that the police confiscated the answers to the questionnaire. An analysis of the remaining 324 responses showed that almost $90 \%$ of Moscow students and teachers aged 17 to 20 years were virgins, and at the age of $21-25$ years $-45.4 \%$. Among those who had never been in a formal marriage, the proportion of

${ }^{6}$ V.P. Tikhonov stated: "Almost all the games of local youth had as their finale the beginning of sexual intercourse." 
those who had sexual experience was 18\% [Zhbankov 1922: 225]. For comparison, in 1957, among the students of Leningrad 99\% of girls were still virgins before the age of 16; by 1971 the figure had dropped slightly, to $94 \%$, and by the early 2000s was down to $42 \%$. In the 2000 s, $20 \%$ of high school girls had a sex life, and a very active one. By the 1990s, the sexual activity of Russian youth began earlier than that of the British, Americans or Norwegians [Golod 1996: 59; Denisenko, Dalla Zuanna 2001: 83-87; Con 1990: 171; 1997: 291].

\section{THE REGULATION OF FERTILITY}

In the last third of the $19^{\text {th }}$ century, methods of regulating fertility began gradually entering people's lives, first in cities among the educated and affluent classes ${ }^{7}$ [Meltsin 1999: 55-62], and then among the urban lower classes and peasants [Mukhina 2012: 147-160; Vishnevsky 2005: 1: 271-276; Diachkov 2003: 207; Moiseenko 1984: 73-86; McLaren 1990; Riddle 1997].

In 1871, the judicial investigator V. Magnitsky presented an essay on criminality to the Russian Geographical Society in which he said that, while Russians considered the expulsion of the fetus to be a terrible sin, nonetheless there were women engaged in this practice in every village. ${ }^{8}$ To cause an artificial miscarriage, peasant women used mechanical means (lifting weights, jumping, tight bandaging and kneading of the abdomen, shaking the whole body, etc.), medicines (from various herbs to consuming mercury and phosphorus internally), aborticide, lengthening the lactation period and abortion. To expel the fetus, women healers gave them mercuric chloride to drink or advised them to swallow small disks of tin. To prevent pregnancy, after coitus women would immediately drink a spoonful of water with gunpowder, having first washed their hands with their urine ${ }^{9}$ [Afinogenov 1903: 327; Fedorov 1994: 18; Shcherbinin 2004: 127-128]. These means, though highly imperfect, nonetheless had some effect (Pilsudski 1910: 14-16).

According to the testimony of a priest of the Novgorod gubernia, F.V. Gilyarovsky, in the 1860s peasants who sought to prevent pregnancy increased the duration of breastfeeding "beyond the legal limits - two Lents", i.e. more than 2 years. "Mothers continue to breastfeed a child up to the age of four or five, sometimes feeding another's child and at times even toothless puppies, not to mention even more unnatural ways of extracting their milk" [Gilyarovsky 1866: 50]. Extending the lactation period was widely practiced in other gubernias too [Afinogenov 1903: 99], up until the 1920s. "If a subsequent pregnancy does not occur for a long time," it was noted in one study of the 1920s, "they breastfeed until the child is too ashamed to continue, until the age of 4, 5 or 7 years" [Sinkevich 1929: 58-59; Afinogenov 1903: 99]. This method did, to some extent, protect women from a new pregnancy, because, according to Russian doctors, about $80 \%$ of women did not menstruate while breastfeeding [Grigoryev 1883].

By the beginning of the $20^{\text {th }}$ century, the range of birth control methods had increased to include abstinence, cyclicity and coitus interruptus, condoms, uterine rings, contraceptive caps,

\footnotetext{
${ }^{7}$ In the last third of the 19 th to the early $20^{\text {th }}$ century the Dolgorukov princes deliberately regulated fertility in order to limit the number of heirs.

${ }^{8}$ RGO, f. 14, op. 1, d. 27.

${ }^{9}$ Ibid.
} 
vaginal douches and suppositories. However, these were used only by educated and wealthy women. Contraception had become such a popular topic among them that a well-known manual, K.I. Drexler's "Contraceptive Means in Modern Marriage", was issued seven times between 1907 and 1914 [Drexler 1929; Bellin 1889; Boryakovsky 1893; Van der Bown 1909; Wojciechowski 1888; Popov 1903; Rohleder 1909].

Abortions. According to church law, all means of preventing pregnancy were considered a sin, and aborticide, with the aid of a potion or the help of a midwife, was punished with a penance of between 5 and 15 years. Under civil law, abortion was banned and punishable, and both doctors and patients were prosecuted. The Penal Code of 1845 equated expulsion of the fetus with infanticide, punishable with hard labor for a period of 4 to 10 years. The view that the use of any means of preventing pregnancy and artificially inducing a miscarriage was a major sin was so common that women who used them carefully concealed the fact from everyone (both from neighbors and doctors) even in the 1920s, when abortions were officially allowed [Sinkevich 1929: 46; Lebina 2007]. Fetuses were most often buried in the earth, under the house; less often they were hidden in manure piles and in winter thrown into rivers and streams. For a long time, not only the church and the law, but also doctors were hostile towards abortion [Lebina 2007; Engelstein 1991: 185-207; 1992: 334-358]. In 1889, at the N. I. Pirogov Third Congress of the Society of Russian Doctors, abortion was recognized as a "moral and social evil". Between 1840 and 1890, the total number of abortions officially authorized for medical reasons in all Russian maternity hospitals was a mere 247; by 1910, if we can judge by St. Petersburg and Moscow, their number had increased almost 5-fold, but still remained low (Mikhailov, 1895: 417; Demograficheskaya modernizatsiya Rossii, 2006: 42].

Time, however, worked in favor of liberalizing abortion. Doctor A.O. Afinogenov, who practiced in the late $19^{\text {th }}$ and early $20^{\text {th }}$ century, along with many participants in the Twelfth Congress of the Society of Russian Physicians, noted in 1913 that by the 1880s the practice of abortion had begun to reach the villages, especially those near cities [Afinogenov 1903: 57, 99; The Twelfth Congress ... 1913: 2: 92, 211]. In the villages, they were carried out mainly by "grannies" and women healers ${ }^{12}$ [Semenova-Tian-Shanskaya 1914: 56-58]. City dwellers had become familiar with abortions earlier, and at the beginning of the $20^{\text {th }}$ century industrial cities were seized by an "abortion epidemic". "In the working environment they began to look at artificial miscarriage as something very ordinary and, moreover, very accessible" [Vigdorchik 1914: 217]. Kharkov physician P.N. Chukhnin, who in 1893 estimated the number of abortions and miscarriages at $22 \%$ of all pregnancies, noted: "Many of his patients expressed their unwillingness to have children, and many talked about the precautionary measures they took to protect themselves from pregnancy; if we add to this the fact that some miscarriages were, apparently, deliberately caused, we will see that a modern woman has a strong desire to limit the number of pregnancies" [Chukhnin 1894: 1: 533].

The number of "criminal" abortions cannot be estimated even roughly from the data on those prosecuted for them, as they were carefully concealed from church and secular authorities. In the 1830s, an average of 108 men and 284 women were charged each year for "the extermination

${ }^{12}$ RGEM (Rossiiskii gosudarstvennyi etnograficheskii muzei), f. 7, op. 1, dd. 68, 216, 473, 499, 552. 
of pregnancy" [Report of the Ministry of Justice 1835-1841]. In subsequent years, the number of abortions increased. Despite this, in 1873, 7 men and 10 women were convicted, in 1892 - 3 and 16, respectively, and in 1913 - 34 and 210 [Svod statisticheskikh svedeniy... 1875, 1896, 1916]. In the years 1897-1906, an average of 8 women in Russia were convicted each year for exterminating a fetus [Gernet 1911: 67]; in 1910-1916 the figure was from 20 to 51 [Bezgin 2004: 174], with 2.5 times more being charged with the crime. The decrease in repression is explained by the fact that under the new judicial statutes of 1864 prosecution for abortion weakened, the "criminals" learned to hide from justice, and perhaps most importantly, not only society but law enforcement agencies began to take a more lenient view of the artificial termination of pregnancy. In 1913, under the influence of the social movement for the abolition of the criminal prosecution of doctors and patients for abortions, The Twelfth Congress of the Society of Russian Physicians supported this request, although not unanimously. In February 1914 a meeting devoted to the topic of abortion was held in St. Petersburg by the Russian group of the International Union of Criminologists, attended by prominent Russian doctors, forensic specialists and lawyers. Two reports were heard, one by M.N. Gernet defending the need for full legalization of abortion, and one by E.M. Kulisher advocating partial legalization (allowed only for medical reasons). After a heated two-day debate in which 30 people participated, the group proceeded to adopt a resolution. By a majority of votes (38 to 20, with 3 abstentions) Gernet's proposal, demanding the exclusion of abortion from criminal offenses, was passed [The Twelfth Congress ... 1913: 2: 25, 88, 92, 211; Gernet 1916; Kulisher 1916; Report X of the general meeting ... 1916: 271-333, 354-398, 400]. Although abortion was legalized only in 1920 [Popov 1994: 5-7], the proposal was undoubtedly applied before that, though under great secrecy. It was assumed that less than $1 \%$ of women who had abortions were actually brought to court, and in $75 \%$ of cases they were acquitted [Tretiy s`ezd Obshchestva russkikh vrachey... 1889: 177-178; Gerneth 1916: 237-238]. According to an approximate and greatly inflated estimate, in St. Petersburg the number of abortions increased 10fold in the last third of the $19^{\text {th }}$ century, which represented about $20 \%$ of the number of births [Sadvokasova 1969: 12]; in Moscow in the 1910s, the figure was about 10,000 per year [Tretiy s`ezd Obshchestva russkikh vrachey ... 1889: 177-178; Gernet 1916: 237-238].

Condoms. Condoms also became an important means of preventing pregnancy. For example, in the city of Kharkov, not Russia's largest, they came into use at the end of the 1860s [Bagaly, Miller 1912: 2: 123]. Starting in the 1890s, they became ubiquitous and widely applied in the educated part of the population. However, for religious reasons and because of their high cost, they did not penetrate into peasant life. Condoms were advertised in newspapers and sold in pharmacies and stores selling medical instruments and rubber goods [Boryakovsky 1893: 886-887: Milyutin 1946: 93-94]. In 1911-1913, according to a price list for imported condoms (they were not manufactured in Russia) of the famous St. Petersburg rubber goods stores G. Godefroi and D. Rogers, as well as other firms, a dozen rubber condoms cost from 0.8 to 6 rubles, while those made from fish bladders cost from 2.5 to 7 rubles - that is, between 7 and 59 kopecks each. But they were not sold by the piece, and to buy a dozen of even the cheapest condoms a peasant or worker would need to work an entire day at one of the most difficult jobs [A Compendium of Statistical and Economic Data ... 1917: 526-527; Cities of Russia ... 1914: 30, 118-119, 264-265, 434-435]. This was rather expensive, but still obtainable. However, while in large cities condoms could be bought freely, residents of most cities and rural areas had to order them by mail and pay for the 
shipping, the cost of which far exceeded the price of the goods. For a simple worker (a peasant, laborer, artisan or petty bourgeois) this was not possible, due both to the high cost and illiteracy.

The regulation of childbirth gradually entered people's lives and began to produce results. Over the 30 years from the 1880 s to the 1910 s, the total birth rate in the country as a whole decreased only by 6.5 points (from 50.4 to 43.9 per thousand). This suggests that the general population did not control the number of their children. According to A.G. Vishnevsky's calculations, at the turn of the $20^{\text {th }}$ century Russian women were using only half of their biological potential (instead of 12-13 times, they gave birth on average 6-7 times ${ }^{10}$ [Novoselsky 1914]), mainly due to the fact that marriage occurred at a later age than before ( 2.38 births), due to poor health and deliberate prevention of births (1.60 births) and to premature death (1.26 births). As we can see, birth control explains only a small share of the decrease in fertility (table 16).

Table 16. Factors determining the average number of children per woman in Russia at the turn of the $20^{\text {th }}$ century

\begin{tabular}{lr}
\hline The average number of children a woman could have given birth to in her life & 12.44 \\
Gave birth to & 6.24 \\
Did not give birth to & 6.20 \\
including: & 1.26 \\
$\quad$ Due to death of some women under 50 & 0.55 \\
Due to some women not getting married & 2.38 \\
Due to not all women getting married at age 16 & 0.41 \\
Due to not getting married after being widowed & 1.60 \\
Due to poor health or deliberate prevention of birth &
\end{tabular}

Source: [Reproduction of the population ... 1983: 282].

Remote rural regions, where the majority of the population lived, were barely affected by the new trends. According to a survey conducted in 1927, 10 years after the revolution, when abortions and contraception were no longer banned, only $9 \%$ of married Ukrainian peasant women used some method of preventing conception, most often coitus interruptus [Tomilin 1987: 107109]. In 1990-1993, David Ransel conducted field research among Russian peasant women from the Novgorod, Smolensk, Moscow, Sverdlovsk and Ulyanovsk regions in order to trace changes in ideas about marriage, birth control, childbirth and childcare during the years of Soviet power. He took down and recorded on tape 89 in-depth interviews (based on a questionnaire that included 44 questions) of 70 Russian and 19 Tatar women. He chose respondents, firstly, from women who had spent their entire lives in the village, and secondly, women of different ages. Ransel divided all the respondents into three generations: those born in 1899-1911 (27 people), in 1912-1930 (45 people) and in 1931-1954 (17 people). Analysis of the interviews led to the following conclusions. The first generation of women, born in 1899-1911, had spent their childhood under the old imperial regime, and their youth in the Soviet village before the institution of the collective farm. They bore many children; interference in the mystery of conception and birth was considered sinful, and attempts to regulate their number were limited to lengthening the lactation period. Their attitude to abortion was quite hostile, so few of them took advantage of the legalization of abortion in 1920-1936. Afraid of the evil eye, they gave birth without any outsiders present (either alone or with the help of a midwife) and a few days later returned to work. Women of the second

${ }^{10}$ Total fertility rate among women of childbearing age (15-49) in 1896-1897 was 7.06. 
generation, born in 1912-1930, for the most part grew up and were educated under Soviet power and the collective farm system. They controlled their fertility through condoms and illegal abortions, since almost the entire reproductive period of their lives occurred during the period that abortion was prohibited (1936-1955). Women of the third generation, born in 1931-1954, as a rule married in the post-Stalin period. They freely controlled their fertility through the use of abortions and condoms. The Tatar peasant women had more similarities to than differences from the Russian peasant women. Their first generation had never known contraception, and had a negative attitude towards abortion. As for the second generation, they also took no practical measures to regulate the number of births other than the prolongation of lactation, did not recognize abortion, and did not use condoms because of the objections of men. Only the third generation of Tatar peasant women began to regulate the birth rate mainly through abortion and condoms [Ransel 2000].

A different pattern was observed among residents of large cities and privileged segments of the population. Fertility in St. Petersburg from 1861-1865 to 1911-1915 fell from 38 to 26 per 1000 people. In Moscow in 1867-1880, the number was already only 23 per 1000, but, unlike Petersburg, by 1911-1913 had risen to 29 per 1,000, due to the huge influx of peasants [Rashin 1956: 234, 239]. This level of fertility indicates that it had begun to be regulated, as is also evidenced by the fact that total and marital fertility had not only inter-estate, but also intra-estate differences. In St. Petersburg in 1907-1912, women of the poor classes gave birth 3 times more often than representatives of the wealthy strata, and the wives of skilled workers half as often as the wives of unskilled workers [Novoselsky 1978: 136-142; Wigdorchik 1914]. A survey of 2,150 students at Moscow University in 1904, mostly from the middle class (67\% of respondents named their families' property status as average), found that $57 \%$ took measures against conception (25\% - coitus interruptus, $16 \%$ - condoms, and 15\% - other) [Chlenov 1907].

\section{Divorce}

Before the beginning of the eighteenth century, the dissolution of marriage was the prerogative of the priest of the corresponding parish. Matrimonial disputes among the privileged strata were resolved primarily on the basis of Byzantine church and judicial law, which had been brought to Rus and translated into the Church Slavonic language. But when it came to the common people, priests were often guided by ordinary law, and therefore there were up to 26 legal grounds for divorce. It was sufficient for both spouses to make a statement to their parish priest and receive from him a so-called divorce letter [Vladimirsky-Budanov 1900: 439-439; Rabinovich 1978: 215216]. In some cases, they even got by without a priest. If both spouses agreed to the divorce, the husband gave his wife a "divorce certificate" and a "letter of settlement ", which replaced the priest's decision. But if one of the parties did not want a divorce, it became a very difficult matter [Latkin 1909: 520-524]. "Unauthorized separations", as they were called in everyday life, took place during the entire period studied. To quantify this phenomenon is impossible - it was not recorded. However, according to the testimony of contemporaries, at the turn of the nineteenth and twentieth centuries such "separations" were more common than in the eighteenth and early nineteenth centuries, which gives us reason to assume that their frequency increased over time. They were practiced among all segments of society ${ }^{11}$ [Rozanov 2004: 298-299; Ivanilov 2002:

${ }^{11}$ RGEM, f. 7 (V.N. Tenishev), op. 1, dd. 32, 279, 401, 431, 517, 519, 552. 
127-129]. An agent of the Ethnographic Bureau, V.N. Tenishev from the Kaluga gubernia, noted in 1900 that there was no formal church divorce among the peasants, who didn't know the first thing about it. Spouses split up de facto, lived separately, sometimes started a new family; divorced women often went to Moscow and sometimes lived, without a wedding, with widowers. Quite often peasants turned to the district court. The court could not give a formal divorce, but only decide who was right, and who was to blame ${ }^{12}$. "Separations" happened more often than one would expect, based on the normative model of demographic behavior. ${ }^{13}$ However, they were not widespread, due to the extremely negative attitude of society, the church and the state towards them ${ }^{14}$ [Tsaturova 2011: 93-160, 256-266; Zabolotnaya 2010].

During the $18^{\text {th }}$ century the Russian Orthodox Church (ROC) transferred the divorce process to the consistory and made it official, reducing the number of formal grounds for divorce to four: 1) proven adultery; 2) an unexplained long absence; 3) a court sentence involving the deprivation of all property rights; 4) the taking of monastic vows by one of the spouses on condition of a mutually amicable agreement, or a simultaneous taking of vows if the wife has reached 50 years of age, and there are no young children. Disagreement between spouses, physical disabilities, serious illnesses and beatings did not serve as a formal basis for divorce, but they did give the spouses some freedom to separate. The establishment of a close relationship or a subsequent marriage by one of the spouses in the absence of the other made the previous marriage null and void. [Svod zakonov ... 1857; Latkin 1909: 520-521]. In 1806, a fifth cause for a legitimate divorce appeared: "physical incapacity for marital cohabitation", which was tantamount to recognizing a serious illness as the basis for a divorce. ${ }^{15}$ The ROC's effective institutional control over matrimonial affairs could be established only after the introduction of the "Charter of Spiritual Consistories" in 1841, which strictly codified the conditions necessary for divorce and its procedure [Freeze 2009: 125-126].

It should be taken into account that spouses (usually women) could, through the Chancellery for the Receipt of Petitions Addressed to the Emperor, obtain the right to live separately without a divorce, which most often meant the de facto termination of marital relations and helped to break the deadlock created by the difficulties of divorce [Mareeva 2003: 33-36]. In the years 1890-1902 an average of 2,327 petitions per year were submitted to the Chancellery by women, of which 1,154 were granted, which is 10-20\% higher than the number of divorces. It is interesting to note that the grounds for filing and granting petitions was different than for divorces (Table 17).

The grounds for divorce recognized by the ROC as legitimate (infidelity, an unexplained long absence or wandering lifestyle, incapacity for married life), figured only in $11.6 \%$ of petitions for separation; in other cases, the grounds were those recognized by the public and de facto crown authorities [Veremenko 2007: 324-337]. If women wanted to divorce and had sufficient formal

\footnotetext{
${ }^{12}$ RGEM, f. 7, op. 1, d. 552, 11. 2-3; d. 279, 11. 2-3; d. 517, 11. 16-18; d 519, 1. 27.

${ }^{13}$ Information received by V.N. Tenishev of the Ethnographic Bureau, partially published [Everday Life of GreatRussian peasant-farmers... 1993; Russian peasants ... 2004-2017].

${ }^{14}$ In Orthodox Moldova in the $16^{\text {th }}-17^{\text {th }}$ centuries, family customs and traditions condemned divorce, but it nonetheless existed, and women even sometimes won their case.

${ }^{15}$ By "incapacity for marital cohabitation" was meant solely a physical inability to perform sexual intercourse, which required the doctor's conclusion about a man's inability and proof of a woman's virginity.
} 
grounds for this, they usually sued in court for divorce; in the absence of such grounds, they petitioned the Chancellery. The right to live separately was, in effect, a substitute for divorce.

Table 17. Grounds for receiving permission to live apart from one's husband in 1891 (for persons of the Orthodox faith)

\begin{tabular}{l|rr}
\hline Grounds & Petitions & $\%$ \\
\hline Violent character, drunkenness, beating, extortion, squandering property & 233 & 39.8 \\
Ill-treatment & 112 & 19.1 \\
Not providing family material support & 108 & 18.5 \\
Depraved life style & 51 & 8.7 \\
Infidelity & 50 & 8.5 \\
Wandering lifestyle & 14 & 2.4 \\
Mental disabilities & 8 & 1.4 \\
Venereal diseases & 5 & 0.9 \\
Incapacity for marital life & 4 & 0.7 \\
Total & 585 & 100.0 \\
\hline
\end{tabular}

Source: [Veremenko 2007: 250].

If we merge the data on divorce and separation permits for the year 1891, it turns out that in about $56 \%$ of cases the reasons for women's unwillingness to remain married were the proverbial five legal grounds for divorce, and in $44 \%$ of cases, other reasons not recognized by the ROC. It is interesting to note that the grounds for separation among Orthodox Christians coincided with the formal conditions for divorce among Russian Protestants; among Catholics, divorce was forbidden, and obtaining the right to separation was fraught with great difficulties. For this reason, Protestants divorced 4 times more often than Orthodox Christians, and 12 times more often than Russian Catholics ${ }^{16}$ [Veremenko 2007: 294, 312, 318].

Table 18. The number of dissolved marriages among the Orthodox population of the Russian Empire in 1842 -1914

\begin{tabular}{l|c|c|c}
\hline Years & Number of divorces & Divorces per 1000 marriages & Divorces per 1000 persons \\
\hline $1842-1850$ & 74 & 0.143 & 0.002 \\
$1851-1860$ & 80 & 0.156 & 0.002 \\
$1866-1870$ & 782 & 1.377 & 0.015 \\
$1871-1880$ & 917 & 1.587 & 0.016 \\
$1881-1890$ & 1068 & 1.698 & 0.030 \\
$1891-1900$ & 1047 & 1.202 & 0.012 \\
$1901-1910$ & 1921 & 2.071 & 0.021 \\
$1911-1915$ & 3650 & 4.302 & 0.037 \\
\hline
\end{tabular}

Source: Estimated according to: [Vsepoddanneyshiy otchet ober-prokurora ... 1842-1914].

Due to the church's strict control over divorce in the late imperial period, they became an extraordinary event, and divorced persons can be considered aberrations [Bechasnov 1893: 8; Novoselsky 1916a: 29; Preobrazhensky 1901: 71-74; Freeze 1990; 2006]. According to information received from eparchies by the Synod, the number of dissolved marriages began to increase rapidly in the 1860s, but until 1917 remained at a low level (Table 18)

\footnotetext{
${ }^{16}$ Data for the years $1867-1876$. Of the total number of divorces and invalid marriages the latter came to about $15 \%$ in the 1840 s, in $1890-1912-3-6 \%$.
} 
Along with the growth in the number of marriages dissolved in the second half of the $19^{\text {th }}$ and beginning of the $20^{\text {th }}$ century, the composition of the grounds for divorce changed radically (Table 19).

Table 19. Grounds for divorce among the Orthodox population of European Russia in the mid-19 ${ }^{\text {th }}$ - early $20^{\text {th }}$ century, $\%$

\begin{tabular}{|c|c|c|}
\hline \multirow{2}{*}{ Grounds for divorce } & \multicolumn{2}{|c|}{ Divorces. \% } \\
\hline & $1841-1850$ & $1905-1912$ \\
\hline Adultery & 6.8 & 97.4 \\
\hline Incapacity for marital life & 3.3 & 2.3 \\
\hline Missing or exiled to Siberia & 89.9 & 0.3 \\
\hline Total & 100.0 & 100.0 \\
\hline
\end{tabular}

Source: Calculated according to [Novoselsky 1916a: 43; Prebrazhensky 1901: 71-74; Vsepoddanneyshiy otchet ober-prokurora ... 1915].

Until the 1850s, the main grounds for divorce were a spouse's unexplained absence and exile to Siberia; at the beginning of the $20^{\text {th }}$ century, adultery was practically the only reason for it $^{17}$ [Veremenko 2007: 317]. Formal divorces occurred mainly among the educated, privileged strata $^{18}$ [Meltsin 1999: 271-277]. In the post-reform period, divorce made its way into the world of peasants, petty bourgeois and merchants. In the city, the number of divorced people per 1000 outpaced those in the village by a factor of 3; in avant-garde Petersburg, it was 7 times greater than in the entire urban population, and 21 times greater than in the entire country. Moscow lagged behind. According to the census of 1902, divorced men made up $1 \%$ of the population, and women - 1.5\% [Perepis' Moskvy ... 1904: 112-113], that is, 1.6 times less than in St. Petersburg. In terms of social class, the nobles were in the lead, divorcing on average 5 five times more often than the clergy and the peasants, and in St. Petersburg - 7 times more often than the clergy and peasants (Table 20).

In terms of the confession of those getting divorced, the leaders were Jews, Muslims and Buddhists; then came Protestants and Catholics, and, last of all, the Orthodox. Compared to Russians, Jews divorced about 9 times more often, Tatars and Bashkirs 8 times more often, Germans and Estonians three times, and Poles and Lithuanians 2 times more often [Obshchiy svod... 1905: Vol.2: 92-97, 176; Veremenko 2007: 374-377]. A significant increase in the number of divorces, especially in the city, reflected the changes that had begun in the demographic behavior of the population, which had occurred as a result of the reforms [Belyakova 2002; Kotlova 2002; Maksimova 1998; Mareeva 2001; 2003; Veremenko 2007; Leschenko 2004; Freese 2009]. The privileged, educated strata of the population accounted for the lion's share of divorces.

Thus, law, custom and practice allowed a person to dissolve a marriage when it became unacceptable to him. The main difficulty was not in the absence of formal opportunities, but in the fact that their implementation required knowledge, time and resources, and encountered opposition

\footnotetext{
${ }^{17}$ Catholics and Protestants had more grounds for divorce, including malicious abandonment without help and harsh treatment. In the Warsaw Consistorial District in 1878-1882, these last two reasons accounted for about half of all divorces.

${ }^{18}$ For example, among the Dolgoruky princes between 1711 and 1900 there were two bigamists, 11 divorcees - 1 in the $1730 \mathrm{~s}, 1$ in the $1810 \mathrm{~s}, 1$ in the $1830 \mathrm{~s}, 3$ in the $1840 \mathrm{~s}, 5$ in the years $1861-1900$ - and a large percentage of bachelors and old maids [Meltsin 1999: 271-277].
} 
from the population (especially the peasantry) that reacted negatively toward the dissolution of a marriage. Therefore, divorces occurred extremely rarely: in 1910-1914, there were at most an average of 3.7 terminations per 1000 marriages per year. For comparison, 100 years later, in 20102014, there were 535 divorces per 1000 marriages, or 146 times more.

Table 20. The number of divorced persons in St. Petersburg by estate in 1910

\begin{tabular}{|c|c|c|c|c|c|c|}
\hline \multirow{2}{*}{ Social class } & \multicolumn{4}{|c|}{ Number of divorced persons } & \multirow{2}{*}{$\begin{array}{l}\text { Class size in the } \\
\text { population. } \%\end{array}$} & \multirow[t]{2}{*}{ Divorce rate } \\
\hline & Men & Women & Both sexes & $\%$ & & \\
\hline Nobles & 452 & 583 & 1035 & 26.4 & 7.2 & 3.7 \\
\hline hereditary & 299 & 299 & 598 & 15.3 & 3.9 & 3.9 \\
\hline personal & 153 & 284 & 437 & 11.1 & 3.3 & 3.4 \\
\hline Clergy & 4 & 6 & 10 & 0.3 & 0.5 & 0.5 \\
\hline Honorable citizens & 169 & 131 & 300 & 7.7 & 4.1 & 1.9 \\
\hline Merchants & 42 & 36 & 78 & 2.0 & 0.7 & 2.8 \\
\hline Lower middle class & 297 & 548 & 845 & 21.6 & 15.5 & 1.4 \\
\hline Retired lower officials & 1 & 1 & 2 & 0.1 & 0.1 & 0.5 \\
\hline Peasants & 522 & 780 & 1302 & 33.2 & 68.8 & 0.5 \\
\hline Natives of Finland & 13 & 44 & 57 & 1.5 & 0.9 & 1.6 \\
\hline Foreign nationals & 38 & 87 & 125 & 3.2 & 1.2 & 2.7 \\
\hline Unknown & 38 & 128 & 166 & 4.2 & 1.1 & 4.0 \\
\hline Total & 1576 & 2344 & 3920 & 100.0 & 100.0 & 1.0 \\
\hline Population. thousands & 997.2 & 908.4 & 1905.6 & & & \\
\hline Divorced per 1000 persons & 1.6 & 2.6 & 2.1 & & & \\
\hline
\end{tabular}

Sources: [Petrograd according to the census ... 1915: part 1: 26-35; Veremenko 2007: 376-377].

If we compare Russia with other European countries, the United States and Japan, it turns out that at the beginning of the twentieth century (1901-1905), in most, not only Protestant, but even Catholic countries (where divorce was more difficult than in Russia), the number of divorces per 1000 people was significantly higher: in the UK - 0.02; France - 0.25; Germany - 0.2; in the USA - 0.8; in Japan - even 1.1, and in Russia - 0.01 (table 21).

Table 21. The number of divorces per 1000 persons from the 1800 s through the 1960 s in Russia and a number of other countries*

\begin{tabular}{l|c|c|r|r|r|r|r|r}
\hline \multirow{2}{*}{ Country } & \multicolumn{8}{c}{ Years } \\
\cline { 2 - 9 } & $1800 \mathrm{~s}$ & $1850 \mathrm{~s}$ & $1880 \mathrm{~s}$ & $1900 \mathrm{~s}$ & $1920 \mathrm{~s}$ & $1930 \mathrm{~s}$ & $1950 \mathrm{~s}$ & $1960 \mathrm{~s}$ \\
\hline Russia & - & 0.028 & 0.032 & 0.01 & 2.0 & 2.6 & 1.8 & 4.1 \\
Austro-Hungary* & - & 0.055 & 0.01 & 0.01 & - & 0.5 & 2.6 & 2.4 \\
England & - & 0.005 & 0.015 & 0.02 & 0.2 & 0.2 & 1.2 & 1.6 \\
USA & - & 0.3 & 0.42 & 0.80 & 3.1 & 3.3 & 4.7 & 5.3 \\
Germany & - & 0.035 & 0.09 & 0.20 & 1.1 & 1.4 & 2.0 & 1.9 \\
France & 0.02 & 0.035 & 0.09 & 0.25 & 1.1 & 1.1 & 1.5 & 1.3 \\
Japan & - & - & - & 1.10 & 1.7 & 1.4 & 1.7 & 1.6 \\
\hline
\end{tabular}

*Austria since 1918.

Source: [Mironov 2015: vol. 3: 353-356].

\section{SOCIAL AND ETHNIC FEATURES OF THE DEMOGRAPHIC TRANSITION}

The degree of change in demographic indicators and the extent to which they affect different regions and individual social strata helps us to assess the depth of the population's involvement in the demographic transition [Mironov 2015: vol.3: 353-356]. Demographic innovations in the city 
were more intensive than in the countryside, in large cities were more significant than in small ones, among the privileged and educated classes were faster than among the lower classes, and began earlier in the western gubernias than in the central and eastern ones (Table 22).

Table 22. Deviation of total fertility from the maximum possible $\left(I_{f}\right)$, including due to changes in the marital fertility rate $(I g)$ and the proportion of married women $\left(I_{m}\right)$ taking into account extramarital fertility $\left(I_{h}\right)$ in 1896-1897 in European Russia and groups of its constituent gubernias*

\begin{tabular}{l|c|c|c|c|c}
\hline Territory & $\begin{array}{c}\text { Population, } \\
\%\end{array}$ & $\begin{array}{c}\text { Total } \\
\text { fertility } \\
\left(I_{f}\right)\end{array}$ & $\begin{array}{c}\text { Marital } \\
\text { fertility } \\
(I g)\end{array}$ & $\begin{array}{c}\text { Proportion of } \\
\text { married women } \\
\left(I_{m}\right)\end{array}$ & $\begin{array}{c}\text { Extramarital } \\
\text { fertility } \\
\left(I_{h}\right)\end{array}$ \\
\hline European Russia & 100.0 & 0.54 & 0.76 & 0.69 & 0.047 \\
Urban population & 12.9 & 0.39 & 0.66 & 0.56 & 0.044 \\
Rural population & 87.1 & 0.56 & 0.78 & 0.71 & 0.019 \\
\hline \multicolumn{7}{c}{ Groups of gubernias } \\
\hline Non-agricultural center & 18.2 & 0.49 & 0.74 & 0.63 & 0.065 \\
Agricultural center & 30.0 & 0.59 & 0.79 & 0.74 & 0.033 \\
Outlying colonized areas & 19.6 & 0.59 & 0.76 & 0.64 & 0.047 \\
West and Southwest & 21.0 & 0.48 & 0.74 & 0.68 & 0.037 \\
North and Northeast & 8.6 & 0.56 & 0.78 & 0.49 & 0.076 \\
Baltic States & 2.6 & 0.29 & 0.57 & 0.032
\end{tabular}

* The above indices (Coale's indices) are related to each other by the following ratio: $I_{f}=I_{g} I_{m}+\left(1-I_{m}\right) I_{h}$.

Maximum fertility is taken to be the fertility of the Hutterites.

Source: [Vishnevsky 1977: 109, 131].

In ethnic and confessional terms, there were more and deeper demographic changes among Jews, Protestants (Germans, Finns, Latvians, Estonians, etc.) and Catholics (Lithuanians, Poles, etc.), and fewer among Orthodox, Islamic, pagan and other non-Christian rural populations (Tables $23,24)$.

Table 23. Marriage status of the population of different religions in European Russia without Poland and Finland in 1897, \%

\begin{tabular}{l|c|c|c|c|c|c|c|c}
\hline \multirow{2}{*}{ Religion } & \multicolumn{2}{|c|}{ Unmarried } & \multicolumn{2}{c|}{ Married } & \multicolumn{2}{c|}{ Widowed } & \multicolumn{2}{c}{ Divorced } \\
\cline { 2 - 10 } & men & women & men & women & men & women & men & women \\
\hline Orthodox & 56.0 & 52.1 & 40.3 & 39.4 & 3.7 & 8.4 & 0.03 & 0.04 \\
Catholics, & 61.6 & 56.5 & 35.6 & 34.3 & 2.8 & 9.1 & 0.06 & 0.09 \\
Lutherans & 61.2 & 57.4 & 36.8 & 36.1 & 1.8 & 6.0 & 0.16 & 0.49 \\
Jews & 58.0 & 45.9 & 39.4 & 45.6 & 2.4 & 8.4 & 0.10 & 0.12 \\
Muslims & 57.1 & 52.0 & 39.5 & 39.6 & 3.3 & 8.3 & 0.06 & 0.08 \\
Average &
\end{tabular}

Source: [Obshchiy svod ... 1905: t.2: XXXVIII].

By 1897, Lutherans and Catholics who lived in the westernmost regions of the empire had the best demographic indicators [Vishnevsky 1977: 130-134; Marchenko 1977: 135-137; Tolts 1977: 138-140]. It should be noted that in the first half of the $19^{\text {th }}$ century the demographic situation in the Baltics was already better than in the rest of Russia. Jews also had good demographic indicators. In some respects, they were even better than those of Catholics and Protestants: the Jewish birth rate was slightly lower, the marriage rate was higher, overall mortality and especially infant mortality were lower, and illegitimate children were virtually nonexistent. Their life expectancy was lower than among the Baltic peoples, perhaps because they had more children, 
whose mortality rate was much higher than that of adults. In order to achieve such results by the end of the $19^{\text {th }}$ century, they must have entered the stage of demographic transition in which the traditional type of reproduction gives way to the modern type in the second half of the $19^{\text {th }}$ century, because in the middle of the century their demographic indicators differed little from those of Orthodox and Muslims. Despite the fact that they lived within the pale of settlement and experienced discrimination, Jews were among the first to enter into this stage of demographic transition.

Table 24. Some demographic characteristics of the population of different religions in European Russia in 1896-1904

\begin{tabular}{|c|c|c|c|c|c|c|c|}
\hline \multirow{3}{*}{ Religion } & \multirow{2}{*}{\multicolumn{2}{|c|}{$\begin{array}{c}\text { Age at marriage, } \\
\text { years }\end{array}$}} & \multicolumn{3}{|c|}{ Total rates per 1000} & \multirow{3}{*}{$\begin{array}{c}\text { Mortality of } \\
\text { newborns per } \\
1000 \text { births }\end{array}$} & \multirow{3}{*}{$\begin{array}{c}\text { Share of } \\
\text { illegitimate } \\
\text { children, \% }\end{array}$} \\
\hline & & & \multirow[t]{2}{*}{ nuptiality } & \multirow[t]{2}{*}{ fertility } & \multirow[t]{2}{*}{ mortality } & & \\
\hline & men & women & & & & & \\
\hline Orthodox & 24.2 & 21.3 & 8.7 & 51.1 & 34.8 & 263.0 & 2.4 \\
\hline Catholics & 29.1 & 23.3 & 6.9 & 36.5 & 22.3 & 151.0 & 3.4 \\
\hline Protestants & 28.5 & 24.6 & 6.8 & 29.2 & 21.0 & 161.0 & 3.7 \\
\hline Jews & 27.5 & 24.1 & 7.3 & 30.7 & 16.0 & 116.0 & 0.4 \\
\hline Muslims & 27.6 & 22.2 & 10.9 & 43.9 & 27.7 & 158.0 & 0.2 \\
\hline Average & 25.1 & 21.8 & 8.5 & 50.1 & 30.9 & 224.0 & 2.3 \\
\hline
\end{tabular}

In the middle of the $19^{\text {th }}$ century, the Muslims of European Russia (primarily the Bashkirs and the Volga and Crimean Tatars) differed little from the Orthodox in their demographic characteristics, but by the end of that century they had pulled ahead somewhat, to a position midway between the Orthodox, on the one hand, and the Catholics and Protestants on the other. It was especially advantageous that they differed from Orthodox believers in low infant mortality [Ershov 1898: 112-116; Materialy po izucheniyu detskoy smertnosti ... 1908: 92-97]. It is worthy of note that nuptiality among Muslims was higher than among Orthodox Christians, and fertility was lower, which indicates that the Tatars used the methods of birth control available to them more actively. Muslims of Central Asia, in terms of their demographic characteristics, were far behind not only European Muslims but also Orthodox [Karakhanov 1977].

The life expectancy for 11 nationalities in Russia in 1897 reflects well the level of demographic development of each of these ethnic groups (Table 25).

Table 25. Life expectancy at birth for 11 nationalities of European Russia in 1896-1897, years

\begin{tabular}{l|c|r|l|l|r}
\hline Nationality & Men & Women & Nationality & Men & Women \\
\hline Russians & 27.5 & 29.8 & Bashkir & 37.2 & 37.3 \\
Chuvash & 31.0 & 31.0 & Moldavian & 40.5 & 40.5 \\
Tatar & 34.6 & 35.1 & Lithuanian & 41.1 & 42.4 \\
Belorussian & 35.5 & 36.8 & Estonian & 41.6 & 44.6 \\
Ukrainian & 36.3 & 39.9 & Latvian & 43.1 & 46.9 \\
Jewish & 36.6 & 41.4 & On average & 31.3 & 33.4 \\
\hline
\end{tabular}

Source: [Ptukha 1928: 37-38].

In terms of this indicator, the Latvians were in first place, and the Russians in last. Ethnic differences in life expectancy were due, first of all, to the differing degrees of involvement of individual ethnic groups in the demographic transition from the traditional to the modern type of population reproduction. The Baltic peoples and Jews took this path earlier than others and by the end of the $19^{\text {th }}$ century they had made considerable progress under the direct influence of the new 
demographic relations taking shape in Western Europe, with which they had closer cultural, religious, economic and other ties. At the turn of the $20^{\text {th }}$ century, the Baltic region was in all respects the most advanced region of Russia. The demographic transition of other ethnic groups began later, and so naturally they achieved less. The second factor determining the differences in life expectancy could be called a cultural one. It depended on their attitude to children, the quality of their care for them, the level of sanitation and all other living conditions that influenced mortality.

\section{DEMOGRAPHIC AND POLITICAL REVOLUTION}

In order to assess how much more effective reproductive behavior has become, three indicators are used: the gross reproduction rate, the net reproduction rate and the cost of simple reproduction (the ratio of gross and net rates), which shows how many girls a woman needs to give birth to in order to ensure the population replacement level, or the simple replacement of the parental generation. It is this ratio that serves as a measure of the efficiency of the reproduction regime, or the regime of the renewal of generations.

According to E.M. Andreev and A.G. Vishnevsky's calculations, the gross reproduction rate decreased between 1851-1863 and 1904-1913 from 3.261 to 3.089, while the net rate rose from 1.442 to 1.636 , respectively, and the population replacement rate dropped from 2.261 to 1.839 [Vosproizvodstvo naseleniya SSSR ... 1983: 273]. Consequently, Russian woman began to give birth less often, but, in spite of this, each new maternal generation became more numerous. Moreover, the replacement of one maternal generation by another began to occur $23 \%$ more efficiently (2.261: 1.839), i.e., with fewer physical costs on the part of the woman and fewer material costs on the part of parents. Of course, this was still a very far from perfect model for the reproduction of the population. Such a regime existed in France and Sweden in the late $18^{\text {th }}$ century. And for developed countries in the 1980s, the population replacement rate was 1.02 in the US and France, 1.0 in Sweden, and 1.0 in Japan, while in the USSR in 1980 it was 1.05 [Demographic encyclopedia . . 1895: 71]. European countries lying to the West of Russia were ahead in their demographic development.

Although the model of population reproduction in the second half of the $19^{\text {th }}$ and early $20^{\text {th }}$ centuries slightly improved, it still remained incredibly difficult for Russian citizens. At the turn of the $20^{\text {th }}$ century, a typical Russian woman of fertile age (from 16 to 49), who married and lived with her husband until the end of the reproductive period (up to 49 years), spent on average 6 years as a maiden, 25 years as a wife, 2 years as a widow and 2 weeks as a divorcee [Vishnevsky, Tolts 1988: 93]. Approximately nine women out of ten had to give birth 8-10 times, which essentially removed them from public and cultural life and by necessity reduced their existence to pregnancy, care for children (about half of whom died), and hard labor, as men could not financially support the family without their help. For example, a peasant woman was forced to work in the fields until late evening the day before giving birth, and after giving birth, which in $97-98 \%$ of cases took place either with the help of village midwives or with no assistance at all, had to return to work on the third or fourth day after birth [Ivanitsky 1898 : 62; Afinogenov 1903: 3-4]. Some births took place right in the fields. 
Women from the urban lower classes were in about the same position. As for those from the privileged strata, they too had to give birth many times, although they had medical care and could rest after birth. This model of population reproduction was also difficult for men, who had to find the means to support a large number of dependents. Each working family incurred enormous expenses for the birth and upbringing of new generations, and nearly half of these expenses were for nothing, due to the enormous mortality of children. These rational and irrational costs held back the economic growth of the country and were an obstacle to improved living standards.

The traditional type of reproduction of the population, with its high fertility and mortality, which sacrificed people for the continuation of the human race, rested on several factors: psychological - a weak development of individuality; economic - a low level of well-being; social - an estate structure that hindered the mobility of the population and the overcoming of social inequality; political - an absence of civil society and of legal opportunities for people to recognize and protect their own interests; governmental - support by the state, the political elite, the scientific community and the general public who were interested in increasing the number of citizens in order to increase the military power of the empire and the growth of the productive forces of society.

Given such strong foundations, it was extraordinarily difficult to change the traditional type of population reproduction. This was a process of breaking down old stereotypes and stable traditions, hence it spanned several decades and ended in European Russia only in the 1950s, when the transition from the traditional to the rational, or modern, type of population reproduction was finally completed. In the West, it had ended 2-3 generations earlier [Vishnevsky 2005; Livi Bacci 2010].

The demographic transition began in the last third of the nineteenth century with a change in attitudes to life, death and the continuation of the human race, when a certain number of people began to realize that the existing state of things was abnormal, that it was necessary to regulate the birth rate and reduce the number of children to a reasonable level. Such people began to reflect, to seek means to improve their condition not in changes from without (from God, the tsar, the authorities), as before, but from within, in their everyday lives, their traditions, themselves, and in their own irrational demographic behavior. The demographic transition was that rare case in the history of Russia when progressive changes took place not through the obsession of the tsar or by the promptings of the authorities, but voluntarily, consciously and individually, in each separate family, and were therefore irreversible. Without exaggeration, we can say that the beginning of the demographic transition was a landmark event, a sign of the emergence of a new active, individualistic personality. In order for a person to effectively control his sexuality and fertility, to mentally and in practice differentiate between sex, matrimony and reproduction (which in traditional society were an inseparable trinity, but in modern society were independent realms, aimed at achieving specific goals) - and this is the essence of the demographic transition - he or she must be sufficiently rational and culturally developed, must possess a modern, rational type of consciousness. This means being capable of self-awareness and self-analysis, of making an adequate assessment of your personal interests and motives of behavior. It means feeling that you are the subject of your actions, striving to change the world around you and your life in accordance with your needs, goals and ideals, setting and carrying out goals [Mironov 2015: vol.3: 508-509]. 
Therefore, it is obvious that people actively and consciously involved in the demographic transition had changed quite deeply psychologically, mentally and culturally, and therefore possessed significant innovative potential. This made them receptive to innovations also in the social, political, cultural, and economic spheres, as well as more prepared for and desirous of transformations in public life.

However, as we have seen, only a small part of the population embraced the demographic transition. If we include in this group all Protestants, Catholics and Jews of both sexes, as well as males with higher and secondary education among Orthodox, Muslims and other non-Christian faiths, then their combined share in 1897 in European Russia (without Poland and Finland) was about 14\%, and by 1917 this had essentially not changed [Obshchiy svod ... 1905: vol.1: XV, XVIII; Brook, Kabuzan 1980: 74-93; Mironov 2012: 587]. This is probably an overestimate, an upper limit. The fact that fourteen percent of the population was involved in the demographic revolution meant that the masses were not prepared for progressive bourgeois-democratic reforms. Eighty-six percent of the population was more sympathetic to the Socialist-Revolutionary, Bolshevik or anarchist programs of insurrection, rebellion, and expropriations, the elimination of dissenters and the construction of paradise on Earth here and now. But it has long been noted: he who wants everything at once, receives nothing gradually. The revolution of 1917 occurred prematurely and did not fulfill the goals originally set by its liberal democratic leaders and organizers. The overwhelming majority of the population was not yet ready to follow them. "The village lives a natural, animal life," wrote the famous ethnographer, M.Y Fenomenov, about the Russian countryside in the early 1920s [Fenomenov 1925: 1: 91], referring to the reproduction of the population. But this conclusion, with certain limitations, can be extended to other spheres of life.

In particular, in Russia, the movement for the emancipation of women (feminism), which began at the turn of the $1850 \mathrm{~s}$ and $1860 \mathrm{~s}$, did not, unlike in the West, become widespread [Kechedzhi-Shapovalov 1902: 132-203; Kradecky 2012; Novikova 2000: 1-28; Stays 2004; Tishkin 1995; Yukina 2007: 459-466; Edmondson 1984; Stites 1991]. At the time of its apogee in 1905, it involved only about 10,000 people, while at that time in the United States there were over 100,000 adherents, and in Denmark about 80,000 - or, given Denmark's size, a dozen times more.

The intrafamilial relations of the vast majority of the population in 1917 remained authoritarian-patriarchal. They were built on the dominance of men, on a hierarchy, on the strict division of roles according to age and gender, the priority of common family interests over individual ones, the inclusion of families in the life of estate organizations that influenced intrafamily relationships. Political anthropologists point to the dependence of the political regime on the type of family relations [Bocharov 2007, 2: 203-217]. The predominance of patriarchalauthoritarian relations in families of all classes supported political absolutism in the state for the reason that authoritarian families fostered in people the features of an authoritarian personality: passivity, conformism, rigidity of thought, a propensity for stereotypes, a lack of critical reflection, sexual repression, fear and aversion to everything new, different and unusual [Adorno 2001: 20, 281-285] - and such people became a fertile social base for authoritarian relations in all spheres of public life, with all the ensuing political, economic and social consequences. 
Thus, as a result of demographic modernization in late imperial Russia, there was a certain rationalization of demographic behavior among a significant part of the population. Demographic indicators improved, the efficiency of population reproduction increased somewhat, and intrafamilial relations were humanized. No less important were the differentiation of sexual, matrimonial and reproductive behavior and the development of fairly effective individual birth control, which are considered in demography as criteria for qualitative modernizing changes in the process of reproducing the population [Zakharov 2003: 19-21].

However, the positive changes observed were due in large part to the fact that about $14 \%$ of the Russian population joined the demographic transition, mainly from the ranks of educated and wealthy people living in large cities, as well as residents of the western regions who were by religion Jews, Catholics and Protestants. Eight-six percent of the population (the predominant part of the rural and urban population of Orthodox, Muslim, pagan and other non-Christian faiths) turned out to be very superficially affected by the new trends. Those people actively and consciously involved in the demographic transition (demographic deviants, in terms of the behavioral and cultural standards of the late $19^{\text {th }}$ - early $20^{\text {th }}$ century) can be considered the innovative human capital of the country. They were significant and necessary for the slow and gradual comprehensive modernization of the country, but not sufficient for rapid and profound revolutionary bourgeois-democratic transformations. The revolution of 1917 was premature. Political midwives hastened and artificially accelerated the birth of the new Russia. But the newborn was premature. As a result, the revolution failed to solve the tasks set by its leaders and organizers.

\section{REFERENCES}

Arkhiv Rossiiskogo gosudarstvennogo etnograficheskogo muzeia (RGEM), f. 7

(Etnograficheskoe biuro V.N. Tenisheva), op. 1, dd. 32, 68, 216, 279, 401, 431, 473, 499,

517, 519, 552 [Archive of the Russian State Ethnographic Museum (RGEM), fond 7

(Ethnographic bureau of V.N. Tenishev), register 1, files 32, 68, 216, 279, 401, 431, 473, $499,517,519,552]$.

Arkhiv Russkogo geograficheskogo obshchestva (RGO), razriad 14 (Kazanskaia guberniia), op. 1, dd. 1, 2, 3; razriad 29 (Permskaia guberniia), op. 1, d. 62 [Archive of the Russian Geographical Society (RGO), series 14 (Kazan gubernia), register 1, files 1, 2, 3; series 29 (Perm gubernia), register 1, file 62].

Rossiiskii gosudarstvennyi istoricheskii arkhiv (RGIA), f. 796 (Kantseliariia Sinoda), op. 138, d. 2476 (Poltavskaia gubernia) [Russian State Historical Archive (RGIA), fond 796 (Chancellery of the Synod), register 138, file 2476.

Adorno T. (2001). Issledovanie avtoritarnoy lichnosti [The authoritarian personality]. Moscow: Serebryanye niti. $416 \mathrm{p}$.

Afinogenov A.O. (1903). Zhizn' zhenskogo naseleniya Ryazanskogo uezda v period detorodnoy deyatel'nosti zhenshchiny [The life of the female population of the Ryazan uyezd during the period of reproductive activities of women]. Saint Petersburg. $136 \mathrm{p}$.

Avdeev A. (2008). Mladencheskaya smertnost' i istoriya okhrany materinstva i detstva v Rossii i SSSR [Infant mortality and the history of the protection of motherhood and childhood in Russia and the Soviet Union]. Demograficheskie issledovaniya [Demographic research]. 14. 
Istoricheskaya demografiya [Historical demography] / M.B. Denisenko, I.A. Troickaja, eds. Moscow: MAKS Press: 14-73.

Bagalej D.I., D.P. Miller (1912). Istoriya goroda Khar'kova za 250 let ego sushchestvovaniya (s 1655 po 1905 g.) [The history of the city of Kharkiv's 250 years of existence (1655-905)]. T.2. Khar'kov: Izdatel'stvo Khar'kovskogo gorodskogo obshchestvennogo upravleniya. 986 p.

Balov A.V. (1898). Ocherki Poshekhon'ya [Essays of Poshekhonye]. Ottisk iz zhurnala «Etnograficheskoe obozrenie» [Reprint from the journal «Ethnographic review»]. Moscow: $1-20$.

Bechasnov P. (1893). Statisticheskie dannye o razvodakh i nedeystvitel'nykh brakakh za 18671886 gg. (po eparkhiyam Evropeyskoy Rossii) [Statistics on divorces and invalid marriages for 1867-1886. (dioceses of European Russia)]. Saint Petersburg: Tsentral'nyy statisticheskiy komitet Ministerstva vnutrennikh del. $33 \mathrm{p}$.

Beljakova E. V. (2002). «Bab'i stony»: Kak razvodilis' v Rossiyskoy imperii ["Indian moaning": divorce in the Russian Empire] // Rodina [Homeland]. 7: 63-67.

Bellin Je.F. (1889). Otravleniya azotnoy kislotoy v svyazi s sistematicheskim upotrebleniem ee dlya tseley plodoizgnaniya [Poisoning with nitric acid in connection with the systematic use of it for the purposes of expelling a fetus] // Vestnik obshchestvennoy gigieny, sudebnoy $\mathrm{i}$ prakticheskoy meditsiny [Bulletin of public hygiene, forensic and practical medicine]. 1 (1): 20-36.

Bezgin V.B. (2004). Krest'yanskaya povsednevnost' (traditsiya kontsa XIX - nachala XX v.) [Peasant daily life (tradition of the late XIX-early XX century)]. Moscow; Tambov: Izdatel'stvo TGTU. 303 p.

Bobrovsky P. (1863). Grodnenskaya guberniya: v 2 t. [Grodno province: in 2 vol.]. 1. Saint Petersburg: Tipografiya Departamenta General'nogo shtaba. 138 p.

Bocharov V.V. (2007). Irratsional'nost' i vlast' v politicheskoy kul'ture Rossii [Irrationality and power in the political culture of Russia] // Antropologiya vlasti [Anthropology of power]. Khrestomatiya po politicheskoy antropologii: $\mathrm{v} 2 \mathrm{t}$. [A reader in political anthropology: in 2 vol] / V.V. Bocharov, ed. Saint Petersburg: Izd-vo Sankt-Peterburgskogo universiteta. 2: 203-217.

Borjakovsky A.G. (1893). O vrede sredstv, prepyatstvuyushchikh zachatiyu [About the dangers of means to prevent conception] // Vrach [Doctor]. 32: 886-887.

Boyarskiy A. I. (1975). Naselenie i metody ego izucheniya [Population and methods of its study]. Moscow: Statistika: 225-238.

Bridger S. (1992). Soviet Rural Women: Employment and family life // Russian peasant women / B. Farnsworth, L.Viola, eds. New York: Oxford university press: 271-293.

Bruk S.I., V.M. Kabuzan (1980). Dinamika etnicheskogo sostava naseleniya Rossii v epokhu imperializma (konets XIX-1917 g.) [Dynamics of ethnic composition of the population of Russia in the age of imperialism (late XIX-1917)] // Istoriya SSSR [History of the USSR]. 3: 74-93.

Bulgakova L. A. (2008). Vnebrachnaya rozhdaemost' v dorevolyutsionnoy Rossii (K voprosu ob odnoy demograficheskoy zagadke) [Extra-marital fertility in pre-revolutionary Russia (On the question of a demographic mystery)] // Stranitsy istorii [Pages of history]. Cb. nauch. statey, posvyashchennykh 65-letiyu prof. G.A. Tishkina [Collection of scientific articles, 
dedicated to the 65th anniversary of Professor G.A. Tishkin] / R.Sh. Ganelina, ed. Saint Petersburg: Izdatel'skiy Dom Sankt-Peterburgskogo universiteta: 367-380.

Bulgakova L.A. (2009). Nevenchannye soldatki: bor'ba za priznanie [Unwed women of the military estate: the struggle for recognition] // Vlast', obshchestvo i reformy v Rossii v XIXnachale XX veka: issled., istoriografiya, istochnikovedenie [Government, society and reforms in Russia in XIX-early XX centuries: research, historiography, source studies]. Antologiya [Anthology] / A.N. Camutali, ed. Saint Petersburg: Olearius Press: 183-214.

Bushnell Dzh. (2011). Polovoe vozderzhanie i tselibat v prikhode Kuplya Gorokhovetskogo uezda Vladimirskoy gubernii v 1750-e-1830-e gg. [Sexual abstinence and celibacy in the parish of Kupel, Gorokhovets district of Vladimir province in 1750-1830] // Staroobryadchestvo: Istoriya; Kul'tura; Sovremennost' [Old Believers: History; Culture; Modernity]. Materialy X Mezhdunar. nauch.-prakt. konf. [Materials of the Xth Intern. scientific-practical conference]. V 2 t. [In 2 vol.]. 2. URL: http://www.borovskold.ru/content.php?page=lonuemcd_rus\&id=115 (accessed: 05.10.2017).

Byt velikorusskikh krest'yan-zemlepashtsev [The daily life of the Great Russian peasant-farmers] (1993). Opisanie materialov Etnograficheskogo byuro knyazya V.N. Tenisheva (na primere Vladimirskoy gubernii) [Description of materials of Ethnographic Bureau of Prince V.N. Tenishev (on the example of Vladimir province)] / B.M. Firsov, I.G. Kiseleva, author-eds. Saint Petersburg: Izdatel'stvo Evropeyskogo Doma. 471 p.

Caturova M.K. (2011). Tri veka russkogo razvoda (XVI-XVIII veka) [Three centuries of Russian divorce (XVI-XVIII century)]. Moscow: Logos. 285 p.

Chlenov M.A. (1907). Polovaya perepis' moskovskogo studenchestva [Sex census of Moscow students] // Russkiy vrach [Russian doctor]. 31-32: 1072-1111.

Chuhnin P.N. (1894). K statistike vykidyshey i prezhdevremennykh rodov sredi narodonaseleniya Rossii [The statistics of miscarriages and premature births among the population of Russia] // Trudy pyatogo s"ezda Obshchestva russkikh vrachey v pamyat' N.I. Pirogova [Proceedings of the fifth Congress of the N.I. Pirogov Society of Russian physicians]. V 2 t. [In 2 vol.]. 1. Saint Petersburg. XCIV, 712, 51 p.

Demograficheskaya modernizatsiya Rossii [Demographic modernization of Russia, 1900-2000] (2006) / A.G. Vishnevsky, ed. Moscow: Novoe izdatel'stvo. 599 p.

Denisenko M.B., Zh.P. Dalla Zuanna (2001). Seksual'noe povedenie rossiyskoy molodezhi [Sexual behavior of Russian youth] // Sotsiologicheskie issledovaniya [Sociological research]. 2: 83-87.

D'jachkov V.L. (2003). Faktory brachno-semeynogo povedeniya zhenshchin v XX v. v zerkale ustnoy istorii [Factors of marital and family behavior of women in the twentieth century in the mirror of oral history] // Zhenskaya povsednevnost' v Rossii v XVIII-XX vv. [Women's everyday life in Russia in XVIII-XX centuries]. Materialy mezhdunar. nauch. konf., 25 sentyabrya [Materials of the international scientific conference, September 25] / P.P. Shherbinin, ed. Tambov: Izd-vo TGU. 206-214.

Dreksler K.I. (1929). Predokhranitel'nye sredstva v sovremennom brake ili kak predokhranit' sebya ot beremennosti, ne pribegaya $\mathrm{k}$ abortu [Precautionary means in a modern marriage or how to protect yourself from pregnancy without resorting to abortion] (1929). Minsk: Avtor. $103 \mathrm{p}$.

Dvenadtsatyy s"ezd Obshchestva russkikh vrachey v pamyat' N.I. Pirogova [The twelfth Congress of the N.I. Pirogov Society of Russian physicians] (1913). Vyp. 2 [Vyp. 2]. Saint Petersburg. 109 p. 
Dvizhenie naseleniya v Evropeyskoy Rossii po gruppam guberniy [Population movement in European Russia by groups of provinces] (1865). 1861-1865. 5 p.

Dvizhenie naseleniya v Rossiyskoy imperii za 1867 god [Population movement in the Russian Empire in 1867] (1872). Saint Petersburg: Tipografiya MVD. 461 p.

Dvizhenie naseleniya v Rossiyskoy imperii za 1910 god [Population movement in the Russian empire in 1910] (1916). Petrograd: Tipografiya Shtaba Petrogradskogo voennogo okruga. $251 \mathrm{p}$.

Edmondson L.H. (1984). The feminist movement in Russia: 1900-1917. Stanford, CA: Stanford university press. $351 \mathrm{p}$.

Engelstein L. (1991). Abortion and the civic order: the legal and medical debates // Russia's women: accommodation, resistance, transformation / B.E. Clements, B.A. Engel, Ch. D. Worobec, eds. Berkeley, CA et al.: University of California press: 185-207.

Engelstein L. (1992). The keys to happiness: sex and the search for modernity in fin-de-siècle Russia. Ithaca; London: Cornell university press. 480 p.

Ershov S. (1898). Materialy dlya sanitarnoy statistiki Sviyazhskogo uezda: Opyt sravnitel'noy demografii russkoy i tatarskoy narodnostey [Materials for health statistics of Sviyazhsk uyezd: An attempt at a comparative demography of the Russian and Tatar peoples]. Saint Petersburg: Tipografiya Yablonskogo i Perott. 197 p.

Farnsworth B. (1992). Rural women and the law: divorce and property rights in the 1920s // Russian peasant women / B. Farnsworth, L. Viola, eds. New York: Oxford university press: 167-188.

Favr V.V. (1910). K voprosu o polovykh snosheniyakh, o venericheskikh boleznyakh i onanizme uchashcheysya molodezhi: rezul'taty khar'kovskoy ankety sredi studentov [On the question of sexual intercourse, sexually transmitted diseases and masturbation of students: results of questionnaire Kharkiv among students]. Kharkov: Tipografiya «Pechatnoe delo»: 1-19.

Fedorov V.A. (1994). Mat' i ditya v russkoy derevne (konets XIX-nachalo XX v.) [Mother and child in the Russian village (the end of XIXth-beginning of XXth centuries)] // Vestnik Moskovskogo universiteta [The Moscow University Herald]. Seriay 8: Istoriya [Series 8: History]. 4: 3-21.

Fenomenov M.Ja. (1925). Sovremennaya derevnya: Opyt kraevedcheskogo obsledovaniya odnoy derevni (derevnya Gadyshi, Valdayskogo uezda, Novgorodskoy gubernii) [The modern village: the experience of the regional survey of one village (village Hadishi, Valdai uyezd, Novgorod province)]. 2. [Moscow; Leningrad: Gosudarstvennoe izdatel'stvo. 211 p.

Freeze G.L. (1990). Bringing order to the Russian family: marriage and divorce in Imperial Russia, 1760-1860 // The journal of modern history. 62 (4): 709-746.

Freeze G.L. (2006). Profane narratives about a holy sacrament: marriage and divorce in late Imperial Russia // Sacred stories: religion and spirituality in modern Russia / M. Steinberg, H. Coleman, eds. Bloomington, Indiana: Indiana university press: 146-178.

Friz G. (2009). Mirskie narrativy. o svyashchennom tainstve: brak i razvod v pozdneimperskoy Rossii [Worldly narratives about a Holy sacrament: marriage and divorce in late Imperial Russia] // Pravoslavie: Konfessiya, instituty, religioznost' (XVII-XX vv.) [Orthodoxy: Confession, institutions, religiosity (XVII-XX centuries)]. Sbornik statey [A collection of articles] / M. Dolbilov, P. Rogoznyy, eds. Saint Petersburg: Izdatel'stvo Evropeyskogo universiteta v Sankt-Peterburge: 122-175. 
Gernet M.N. (1911). Detoubiystvo: sotsiologicheskoe i sravnitel'no-yuridicheskoe issledovanie [Infanticide: a sociological and comparative-legal study]. Moscow: Tipografiya Imperatorskogo Moskovskogo universiteta. 318 p.

Gernet M.N. (1916). Istreblenie ploda s ugolovno-sotsiologicheskoy tochki zreniya [The extermination of the fetus from the criminal-sociological point of view] // Otchet X obshchego sobraniya Russkoy gruppy Mezhdunarodnogo soyuza kriminalistov 13-16 fevralya 1914 g. v Peterburge [Report of the X General meeting of the Russian group of the International Union of criminologists 13-16 Feb 1914 in St. Petersburg]. Petrograd: 233-277.

Giljarovsky F.V. (1866). Issledovanie o rozhdenii i smertnosti detey v Novgorodskoy gubernii [A study on birth and mortality of children in Novgorod province]. Saint Petersburg: Tipografiya K. Vul'fa. 664 p.

Golod S.I. (1996). XX vek i tendentsii seksual'nykh otnosheniy v Rossii [The twentieth century and trends in sexual relations in Russia]. Saint Petersburg: Aleteyya. 191 p.

Goroda Rossii v 1910 godu [Cities of Russia in 1910] (1914). Saint Petersburg: Tipografiya N.L. Nurkina. 1200 p.

Grigoryev I. (1883). O polevoi deiatel'nosti zhenshchin Myshkinskogo uezda Iaroslavskoi gubernii [On the sexual activity of women of the Myshkin district of the Yaroslavl gubernia]. Vrachebnye vedomosti. 21/23.

Hajnal J. (1965). European marriage patterns in perspective // Population in history / D.D. Glass, D.E.C. Eversley, eds. London : Edward Arnold publishers: 101-143.

Hanykov Ja.V. (1851). Ocherk istorii meditsinskoy politsii v Rossii [Essay on the history of medical law in Russia]. Saint Petersburg: Tipografiya Ministerstva vnutrennikh del. 114 p.

Hlopin G., I. Erisman (1899). Meditsina i narodnoe zdravie [Medicine and public health] // Entsiklopedicheskiy slovar' [Encyclopedic dictionary] / F.A. Brokgauz, I.A. Efron, eds. 27-a: Rossiya [Russia]. Saint Petersburg: Tipografiya Aktsionernogo obshchestva «Izdatel'skoe delo»: 214-227.

Istoriko-statisticheskie tablitsy po Yaroslavskoy gubernii za 1862-1898 gg. [Historical and statistical tables on Yaroslavl province for 1862-1898] (1901). Yaroslavl: Tipografiya Gubernskoy zemskoy upravy. 87 p.

Ivanicky N. (1898). Sol'vychegodskiy krest'yanin, obstanovka ego zhizni i deyatel'nost' [Solvychegodsk peasant, the circumstances of his life and activities] // Zhivaya starina [Living antiquity]. 1 (8): 3-74.

Ivanilova E.P. (2002). Problema sushchestvovaniya grazhdanskikh brakov v Tambovskoy gubernii, XIX v. [The problem of the existence of civil marriages in Tambov province, XIX century] // Sotsial'naya istoriya rossiyskoy provintsii v kontekste modernizatsii agrarnogo obshchestva v XVII-XX vv. [Social history of the Russian province in the context of modernization of agrarian society in the XVII-XX centuries]. Materialy mezhdunar. konf., may [Materials of Intern. conf., may] / V.V. Kanishhev, ed. Tambov: Izdatel'stvo TGU: 127129.

Jakovlev Ja. (1923). Derevnya kak ona est' [The village as it is]. Moscow: Krasnaya nov'. 132 p.

Jakovlev Ja. (1924). Nasha derevnya: Novoe v starom i staroe v novom [Our village: the new in the old and the old in the new]. Moscow: Krasnaya nov'. 180 p.

Jukina I.I. (2007). Russkiy feminizm kak vyzov sovremennosti [Russian feminism as a challenge of modernity]. Saint Petersburg: Aleteyya Istoricheskaya kniga. 539 p. 
Karahanov M.K. (1977). Demograficheskie protsessy v Sredney Azii vo vtoroy polovine XIX stoletiya [Demographic processes in Central Asia in the second half of the nineteenth century] // Brachnost', rozhdaemost', smertnost' v Rossii i v SSSR [Marriages, births and deaths in Russia and in the USSR] / A.G. Vishnevsky, ed. Moscow: Statistika: 191-213.

Kechedzhi-Shapovalov M.V. (1902). Zhenskoe dvizhenie v Rossii i za granitsey [The women's movement in Russia and abroad]. Saint Petersburg: Tipografiya E. Evdokimova. 210 p.

Kon I.S. (1990). Vvedenie v seksologiyu [Introduction to sexology]. Moscow: Meditsina. 336 p.

Kon I.S. (1997). Seksual'naya kul'tura v Rossii: Klubnichka na berezke [Sexual culture in Russia: Strawberry on the birch]. Moscow: O.G.I. 460 p.

Kotlova T.B. (2002). Zamuzhestvo i razvod v zhizni gorozhanki na rubezhe XIX - XX vv. (po materialam tsentral'nykh guberniy Rossii) [Marriage and divorce in the life of urban women at the turn of XIX - XX centuries (based on materials of the central provinces of Russia)] // Adam i Eva [Adam and Eve]. 3: 154-172.

Kradeckaja S.V. (2012). Grazhdanskaya identichnost' feministok v Rossii v nachale XX v.: diss. ... kand. ist. nauk. [Civic identity of feminists in Russia in the early XX century: abstract Ph.D]. Moscow.

Krjukova S.S. (1992). Brachnye traditsii yuzhnorusskikh guberniy vo II pol. XIX v. [Marital customs of the southern Russian provinces in the second half of the XIX ${ }^{\text {th }}$ century.] // Etnograficheskoe obozrenie [The ethnographic review]. 4: 41-50.

Kulisher E.M. (1916). Nakazuemost' aborta [The punishment for abortion]. Otchet X obshchego sobraniya Russkoy gruppy Mezhdunarodnogo soyuza kriminalistov 13-16 fevralya $1914 \mathrm{~g}$. v Peterburge [Report of the Xth General meeting of the Russian group of the International Union of criminologists 13-16 Feb 1914 in St. Petersburg]. Petrograd: 245-255.

Laptev M. (1861). Kazanskaya guberniya [Kazan province]. Saint Petersburg: Voennaya tipografiya. $616 \mathrm{p}$.

Latkin V.N. (1909). Uchebnik istorii russkogo prava perioda imperii: (XVIII i XIX st.) [A textbook of the history of Russian law of the period of the Empire: (XVIII and XIX centuries)]. Saint Petersburg: Tipografiya Montvida. 644 p.

Lebina N. (2007). «Navstrechu mnogochislennym zayavleniyam trudyashchikhsya zhenshchin...»: Abortnaya politika kak zerkalo sovetskoy sotsial'noy zaboty // Sovetskaya sotsial'naya politika 1920-kh-1930-kh godov: ideologiya i povsednevnost' ["To meet the numerous allegations of women workers...": Abortion policy as a mirror of Soviet social care // Soviet social policy 1920s-1930s: ideology and everyday life] / P. Romanov, E. Yarskaya-Smirnova, eds. Moscow: Variant: 228-241.

Leshchenko V.Ju. (2004). Russkaya sem'ya (XI-XIX vv.) [The Russian Family (XI-XIX c.)]. Saint Petersburg: SPGUTD. 607 p.

Lipinsky A.I. (1868). Simbirskaya guberniya [Simbirsk province]. V 2 chastyakh [In 2 parts]. 2. Saint Petersburg: Voennaya tipografiya. 761 p.

Livi Bacci M. (2010). Demograficheskaya istoriya Evropy [The demographic history of Europe]. Saint Petersburg: Alexandria. 298 p.

Lukanin A. (1878). Naselenie Okhanskogo uezda Permskoy gubernii po sosloviyam, vozrastam i semeynomu sostavu [The population of Okhansk district of Perm province on estates, ages, and family composition] // Zapiski Russkogo geograficheskogo obshchestva po otdeleniyu statistiki [Notes of the RGS, Department of statistics]. 5. Saint Petersburg: Tipografiya V. Kirshbauma. 
Maksimova T.O. (1998). Razvod po-russki [Divorce the Russian way] // Rodina [Homeland]. 9: 55-60.

Marchenko O.V. (1977). Indeksy rozhdaemosti po 50 guberniyam Evropeyskoy Rossii v kontse XIX v. [Indices of fertility for 50 provinces of European Russia in the late nineteenth century] // Brachnost', rozhdaemost', smertnost' v Rossii i v SSSR [Nuptiality, fertility, and mortality in Russia and in the USSR] / A.G. Vishnevsky, ed. Moscow: Statistika: 128-137.

Mareeva E.P. (2001). Muzhchiny i zhenshchiny pri zaklyuchenii i rastorzhenii braka v XIX v. (po materialam Tambovskoy eparkhii) [Men and women in the conclusion and dissolution of marriage in the $\mathrm{XIX}^{\text {th }}$ century (on materials of Tambov diocese)] // Ot muzhskikh i zhenskikh $\mathrm{k}$ gendernym issledovaniyam [From men's and women's studies to gender studies]. Materialy mezhdunar. nauch. konf., 20 aprelya [Proceedings of the international. scientific. Conf., 20 Apr.] / P.P. Shherbinin, ed. Tambov: Izdatel'stvo TGU: 38-42.

Mareeva E.P. (2003). Problema polucheniya zhenshchinami prava na otdel'noe ot supruga prozhivanie (na materialakh Tambovskoy gubernii, XIX -nachalo XX v.) [The problem of women obtaining the right to live separately from a spouse (on materials of Tambov province of XIX-beginning of XX century)] // Zhenskaya povsednevnost' v Rossii v XVIII-XX vv. [Women's everyday life in Russia in XVIII-XX centuries]. Materialy mezhdunarodnoy nauchnoy konferentsii, 25 sentyabrya [Materials of the international scientific conference, 25 sept.] / P.P. Shherbinin, ed. Tambov: Izdatel'stvo TGU: 33-37.

Materialy po izucheniyu detskoy smertnosti v Saratovskoy gubernii s 1902 po 1904 g. [Materials for the study of child mortality in the Saratov province from 1902 to 1904] (1908). V 3 vyp. [In 3 parts]. 2 / N.I. Tezjakov, comp. Saratov: Saratovskoe gubernskoe zemstvo. 285 p.

McLaren A. (1990). A history of contraception from antiquity to the present. Oxford, UK; Cambridge, Mass., USA: B. Blackwell. 275 p.

Mel'cin M. O. (1999). Sud'by starinnogo rossiyskogo dvoryanstva v kontse XVIII-nachale XX veka: Knyaz'ya Dolgorukovy v sisteme obshchestvennykh otnosheniy: diss. ... kand. ist. nauk [The fate of the old Russian nobility in the late XVIII-early XX century: The Dolgorukov princes in the system of social relations: PhD abstract]. Saint Petersburg.

Mihajlov V.M. (1895). Srednie russkie akusherskie itogi za pyat'desyat let po materialam pechatnykh otchetov rodovspomogatel'nykh uchrezhdeniy, 1840-1890 [The average Russian obstetric outcome for fifty years based on materials of the printed reports of maternity services, 1840-1890]. Novgorod: Tipografiya I.I. Ignatovskogo. 448 p.

Miljutin V. (1946). Izbrannye proizvedeniya [Selected works]. Moscow: Gosudarstvennoe izdatel'stvo politicheskoy literatury. $448 \mathrm{p}$.

Minh A.H. (1890). Narodnye obychai, sueveriya, predrassudki i obryady krest'yan Saratovskoy gubernii [Folk customs, superstitions, prejudices and rituals of the peasants of Saratov province]. Saint Petersburg: Tipografiya V. Bezobrazova i K ${ }^{\circ} 152 \mathrm{p}$.

Mironov B.N. (1990). Russkiy gorod v 1740-1860-e gody: Demograficheskoe, sotsial'noe i ekonomicheskoe razvitie [The Russian city in the 1740s-1860s: Demographic, social and economic development]. Leningrad: Nauka. 271 p.

Mironov B.N. (1991). Istoriya v tsifrakh [History in numbers]. Leningrad: Nauka. 165 p.

Mironov B.N. (2012). Blagosostoyanie naseleniya i revolyutsii v imperskoy Rossii, XVIIInachalo XX veka [The welfare of the population and revolution in Imperial Russia XVIIIbeginning of XX century]. Moscow: Ves' mir. 844 p. 
Mironov B.N. (2014). Rossiyskaya imperiya: ot traditsii k modernu: v 3 t. [The Russian Empire: from tradition to modernity: in 3 vol]. 1. Saint Petersburg: Dmitrij Bulanin. 896 p.

Mironov B.N. (2015). Rossiyskaya imperiya: ot traditsii k modernu: v 3 t. [The Russian Empire: from tradition to modernity: in 3 vol]. 3. Saint Petersburg: Dmitrij Bulanin. 992 p.

Moiseenko T.L. (1984). Metody izucheniya vnutrisemeynogo kontrolya nad rozhdaemost'yu : (obzor) [Methods of study of family control of fertility (review)] // Demografiya zapadnoevropeyskogo Srednevekov'ya v sovremennoy zarubezhnoy istoriografii : K XVI Mezhdunar. kongressu ist. nauk (Shtutgart, 1985) [The Demography of the Western European Middle Ages in Modern Foreign Historiography: For the XVI International Congress East. Sciences (Stuttgart, 1985)]. Referativnyy sbornik [Collection of abstracts]. Moscow: INION: 73-86.

Muhina Z.Z. (2012). Plodoizgnanie i kontratseptsiya v traditsionnoy krest'yanskoy kul'ture Evropeyskoy Rossii (vtoraya polovina XIX-30-e gg. XX v.) [Abortion and contraception in the traditional peasant culture of European Russia (second half XIX to the 30s of XX century)] // Etnograficheskoe obozrenie [Ethnographic review]. 3: 147-160.

Nikologorsky S.A. (2012). Semeynyy vopros v rossiyskoy publitsistike kontsa XIX — nachala XX veka: avtoref. ... kand. ist. nauk [The family question in Russian journalism of the late XIX - early XX century: PhD abstract]. Moscow: Moskovskiy gosuarstvennyy universitet im. M.V. Lomonosova. $30 \mathrm{p}$.

Novikova N. (2000). Liberal'nyy feminizm v Rossii i na Zapade: opyt sravnitel'nogo analiza [Liberal feminism in Russia and the West: an attempt at a comparative analysis]. URL: www.kennan.yar.ru/seminars/novikova-24102000.html (accessed: 01.10.2017).

Novoselsky S.A. (1916a). Obzor glavneyshikh dannykh po demografii i sanitarnoy statistike Rossii [Overview of the most important data on demographic and health statistics in Russia] // Kalendar' dlya vrachey vsekh vedomstv na 1916 god: v $2 \mathrm{ch}$. [Calendar for physicians of all departments in 1916: in 2 vol]. 2. Saint Petersburg: K.L. Riker: 14-93.

Novoselsky S.A. (1916b). Smertnost' i prodolzhitel'nost' zhizni v Rossii [Mortality and life expectancy in Russia]. Petrograd: Tipografiya Ministerstva vnutrennikh del. 208 p.

Novoselsky S.A. (1978). Demografiya i statistika: izbrannye proizvedeniya [Demography and statistics: Selected works]. Moscow: Statistika. 269 p.

Novoselsky S.A. (1914). K voprosu o ponizhenii smertnosti i rozhdaemosti v Rossii [The question of the reduction of mortality and fertility in Russia]. Saint Petersburg: Tipografiya MVD. 16 p.

O sostave i dvizhenii naseleniya po guberniyam Nizhegorodskoy i Yaroslavskoy [On the composition and movement of population in the provinces of Nizhny Novgorod and Yaroslavl] (1861). Saint Petersburg: Tipografiya S.N. Bekeneva. 105 p.

Obshchiy svod po imperii rezul'tatov razrabotki dannykh Pervoy vseobshchey perepisi naseleniya, proizvedennoy 28 yanvarya $1897 \mathrm{~g}$. [General digest of the results of the formulation of data for the Empire from the First General census of the population produced 28 January 1897] (1905). V 2 t. [In 2 vol.] / N.A. Trojnicky, ed. Saint Petersburg: N.L. Nyrkin.

Otchet Ministerstva yustitsii za 1834-1840 god [The report of the Ministry of justice for [1834-1840] (1835-1841). Saint Petersburg: Tipografiya Pravitel'stvuiushchego Senata.

Otchet X obshchego sobraniya Russkoy gruppy Mezhdunarodnogo soyuza kriminalistov 13-16 fevralya $1914 \mathrm{~g}$. v Peterburge [Report of the X General meeting of the Russian group of the 
International Union of criminologists 13-16 Feb 1914 in St. Petersburg] (1916). Petrograd. $400 \mathrm{p}$.

Pamjatnaja knizhka Voronezhskoj gubernii na 1861 god [Yearbook of Voronezh province in 1861] (1861). Voronezh: Tipografiya V. Gol'dshtejna. 358 p.

Pamjatnaja knizhka Voronezhskoj gubernii na 1870 - 71 god [Yearbook of Voronezh province in the year 1870-71] (1871). Voronezh: Tipografiya V. Gol'dshtejna. 346 p.

Patterns of first marriage: timing and prevalence (1990). New York: United Nations. 327 p.

Perepis' Moskvy 1902 goda [The census of Moscow 1902] (1904). V 4 vyp. [In 4 parts]. 1. Naselenie. [Population]. 1. Naselenie po polu, vozrastu, mestorozhdeniyu, prodolzhitel'nosti prebyvaniya v Moskve, semeynomu sostoyaniyu, sosloviyam, gramotnosti i stepeni obrazovaniya [Population by sex, age, birthplace, duration of stay in Moscow, family composition, estate, literacy and level of education]. Moscow: Stat. otd. Mosk. Gor. upravy $155 \mathrm{p}$.

Petrograd po perepisi naseleniya 15 dekabrya 1910 goda: naselenie [Petrograd census of the population 15 Dec 1910: population] (1915). V 2 ch. [In 2 vol.] Ed. by Vladimir Stepanov. 1. Petrograd: Izdanie Gorodskoy upravy po Statisticheskomu otdeleniyu. 339 p.

Pilsudskij B. (1910). Rody, beremennost', vykidyshi, bliznetsy, urody, besplodie i plodovitost' u tuzemtsev ostrova Sakhalina [Childbirth, pregnancy, miscarriage, twins, deformity, infertility and fertility of the natives of the island of Sakhalin] // Zhivaya starina [Living antiquity]. 7374. I-II: $22-48$.

Popov A.A. (1994). Kratkaya istoriya aborta i demograficheskoy politiki v Rossii [A brief history of abortion and demographic policy in Russia] // Planirovanie sem'i v Evrope [Family planning in Europe]. 1: 5-7.

Popov G.I. (1903). Russkaya narodno-bytovaya meditsina: Po materialam etnograficheskogo byuro kn. V.N. Tenisheva [Russian folk-domestic medicine : According to materials of the ethnographic bureau book of V.N. Tenishev]. Saint Petersburg: Tipografiya A.S. Suvorina. $404 \mathrm{p}$.

Poprocky M. (1864). Kaluzhskaya guberniya. V 2 t. [Kaluga province: in 2 vol.]. 1. Saint Petersburg: Tipografiya Je. Vejmara. 706 p.

Preobrazhensky I. (1901). Otechestvennaya tserkov' po statisticheskim dannym s 1840-41 po 1890-91 gg. [The Russian Church according to statistics from 1840-41 and 1890-91]. Saint Petersburg: Tipografiya E. Evdokimova. 236 p.

PS3: Polnoe sobranie zakonov. [PS3: Complete collection of laws] (1850). St. Petersburg: Tip. Vtorogo otd. sob. EIV kants. T. 35. Otd. 1. No, 23906

Complete collection of laws (1850) vol.35. section 1. № 23906. SPb .: Printing office of the Second Section of his Imperial Majesty's own registry. канцелярии.

Ptuha M. (1928). Smertnost' 11 narodnostey Evropeyskoy Rossii v kontse XIX veka [Mortality in 11 Nations in European Russia in the late XIX century]. Kiev: TsSU Uainy. 56 p.

Rabinovich M.G. (1978). Ocherki etnografii russkogo feodal'nogo goroda: Gorozhane, ikh obshchestvennyy i domashniy byt [Essays on the ethnography of the Russian feudal city: Citizens, their public and home life]. Moscow: Nauka. 328 p.

Ransel D. (1982). Problems in measuring illegitimacy in prerevolutionary Russia // Journal of social history 16 (2): 11-27. 
Ransel D.L. (1988). Mothers of misery: child abandonment in Russia. Princeton, NJ: Princeton university press. $300 \mathrm{p}$.

Ransel D.L. (2000). Village mothers: three generations of change in Russia and Tataria. Bloomington and Indianapolis: Indiana university press. $314 \mathrm{p}$.

Rashin A.G. (1956). Naselenie Rossii za 100 let (1811-1913 gg.) [The population of Russia for 100 years (1811-1913)]. Statisticheskie ocherki [Statistical essays]. Moscow: Gosstatizdat. $352 \mathrm{p}$.

Riddle J.M. (1997). Eve's herbs: a history of contraception and abortion in the West. Cambridge, Mass.: Harvard university press. 352 p.

Riddle J.M. (2001). Birth, contraception, and abortion // Encyclopedia of European social history from 1350 to 2000. In 6 vols. 2 / P. Stearns, ed. New York etc. : Charles Scribner's Sons: 181-191.

Roleder G. (1909). Kak predupredit' beremennost' [How to prevent pregnancy]. Moscow: Tipografiya S.P. Semenova. 87 p.

Rozanov N.P. (2004). Vospominaniya starogo moskvicha [Memories of an old Muscovite]. Moscow: Russkiy mir". 429 p.

Russkie krest'yane. Zhizn'. Byt. Nravy [The Russian peasants: Life, home, customs] (20042017). Materialy «Etnograficheskogo byuro» knyazya V.N. Tenisheva [Materials of «The Ethnographic Bureau» of Prince V.N. Tenishev]. 1. Kostromskaya i Tverskaya gubernii [Kostroma and Tver provinces]. 2. Yaroslavskaya guberniya [Yaroslavl province]. 3. Kaluzhskaya guberniya [Kaluga province]. 4. Nizhegorodskaya guberniya [Nizhny Novgorod province]. 5. Vologodskaya guberniya [Vologda province]. 6. Kurskaya, Moskovskaya, Olonetskaya, Pskovskaya, Sankt-Peterburgskaya i Tul'skaya gubernii [Kursk, Moscow, Olonets, Pskov, St. Petersburg and Tula province]. 7. Novgorodskaya guberniya [Novgorod province]. 9. Kazanskaya guberniya. Spasskiy i Laishevskiy uezdy [Kazan province. Laishevsky and Spassky districts]. Saint Petersburg: Delovaya poligrafiya.

Sadvokasova E.A. (1969). Sotsial'no-gigienicheskie aspekty regulirovaniya razmerov sem'i [Socio-hygienic aspects of family planning]. Moscow: Meditsina. $191 \mathrm{p}$.

Sankt-Peterburg (1868). Sankt-Peterburg: issledniya po istorii, topografii i statistike stolitsy [Sankt-Peterburg: A study of the history, topography, and statistics of the capital]. V 3 t. [In 3 vol.]. 3. 1. Saint Petersburg: Tipografiya V. Bezobrazova. 207 p.

Sbornik statistiko-ekonomicheskikh svedeniy po sel'skomu khozyaystvu Rossii i inostrannykh gosudarstv [Collection of statistical and economic information on the agriculture of Russia and foreign states] (1917). God devyatyy [Ninth year]. Petrograd: Tipografiya I.F. Vaysberga. $649 \mathrm{p}$.

Sbornik svedeniy po Rossii za 1884-1885 gg. [Collection of information on Russia in 18841885] (1887). Saint Petersburg: Tsentral'nyy statisticheskiy komitet Ministersva vnutrennikh del. $295 \mathrm{p}$.

Semenov Ju.I. (1996). Perezhitki pervobytnykh form otnosheniya polov v obychayakh russkikh krest'yan XIX-nachala XX v. [Vestiges of the primitive forms of gender relations in the customs of the Russian peasants in the XIX to the beginning of XX century] // Etnograficheskoe obozrenie [The ethnographic review]. 1: 39-46.

Semenova-Tjan-Shanskaja O.P. (1914). Zhizn' «Ivana»: ocherki iz byta krest'yan odnoy iz chernozemnykh guberniy [The life of "Ivan": essays from the life of the peasants of the black earth provinces]. Saint Petersburg: Tipografiya M.M. Stasyulevicha. 135 p. 
Shcherbinin P.P. (2002). Nezakonnorozhdennye deti v sem'yakh soldatok v XVIII-XIX vv. [Illegitimate children in the families of the wives of soldiers in the XVIII-XIX centuries] // Sotsial'naya istoriya rossiyskoy provintsii v kontekste modernizatsii agrarnogo obshchestva $\mathrm{v}$ XVII-XX vv. [Social history of the Russian province in the context of the modernization of agrarian society in the XVII-XX centuries]. Materialy mezhdunarodnoy konferentsii (may 2002) [Materials of the international conference (May 2002)] / V.V. Kanischev, ed. Tambov: Izdatel'stvo TGU: 142-146.

Shcherbinin P.P. (2004). Voennyy faktor v povsednevnoy zhizni russkoy zhenshchiny v XVIIInachale XX $v$. [The military factor in the daily life of Russian women in the XVIII-early XX century]. Tambov: Yulis. 507 p.

Sifman R.I. (1977). Dinamika chislennosti naseleniya Rossii za 1897-1914 gg. [Dynamics of population numbers in Russia in 1897-1914] // Brachnost', rozhdaemost', sem'ya v Rossii i v SSSR [Nuptiality, fertility, and family in Russia and in the USSR] / A.G. Vishnevsky, ed. Moscow: Statistika: 62-82.

Sinkevich G.P. (1929). Vologodskaya krest'yanka i ee rebenok [The Vologda peasant and her child]. Moscow; Leningrad: Gosudarstvenoe meditsinskoe izdatel'stvo. 90 p.

Stajts R. (2004). Zhenskoe osvoboditel'noe dvizhenie v Rossii: Feminizm, nigilizm i bol'shevizm, 1860 - 1930 [The women's liberation movement in Russia: Feminism, nihilism and Bolshevism, 1860-1930]. Moscow: Rosspen. 616 p.

Stal' N.E (1867). Penzenskaya guberniya [Penza province]. V 2 ch. [In 2 vol.]. 2. Saint Petersburg: Tipografiya Burgelya. 469 p.

Statisticheskiy ezhegodnik Rossii 1914 g. [Statistical Yearbook of Russia 1914] (1915). II. Petrograd: Tipografiya Shtaba Petrogradskogo voennogo okruga. 119 p.

Statisticheskiy ezhegodnik Rossii 1915 g. [Statistical Yearbook of Russia 1915] (1916). II. Petrograd: CSK. 58 p.

Statisticheskiy ezhegodnik Rossii 1916 g. [Statistical Yearbook of Russia 1916] (1918). 1. Moscow: Tipografiya Moskovskogo Soveta rabochikh, soldatskikh i krest'yanskikh deputatov. $90 \mathrm{p}$.

Statisticheskiy ezhegodnik S.-Peterburga za 1901-1902 gg. [Statistical Yearbook of St. Petersburg for 1901-1902] (1905). Saint Petersburg: S.-Peterburgskaya gorodskaya tipografiya. $761 \mathrm{p}$.

Stites R. (1991). The women's liberation movement in Russia: feminism, nihilism, and bolshevism, 1860-1930. Princeton: Princeton university press. $464 \mathrm{p}$.

Svod statisticheskikh svedeniy po delam ugolovnym proizvedennym v 1873, 1892, 1913 godu [Digest of statistical information on criminal cases made in 1873, 1892, 1913 year] (1875, 1896, 1916). Saint Petersburg: Ministerstvo yustitsii.

Svod zakonov Rossiyskoy imperii [Digest of the laws of the Russian Empire] (1857). X. 1. Zakony grazhdanskie [The civil laws]. Saint Petersburg: Vtoroe otdelenie sobstvennoy ego imperatorskogo velichestva kantselyarii. 491, 104 p.

Tikhonov V.P. (1891). Materialy dlya izucheniya obychnogo prava sredi krest'yan Sarapul'skogo uezda Vyatskoy gubernii [Materials for the study of customary law among the peasants of Sarapul district of Vyatka province] // Sbornik svedeniy dlya izucheniya byta krest'yanskogo naseleniya Rossii [Collection of information for the study of life of the peasant population of Russia]. 3. / N. Haruzin, ed. Moscow: Tipografiya A. Levenson i K. 146 p. 
Tishkin G.A. (1995). Zhenskiy vopros v istorii Rossii [The woman question in the history of Russia] // Feminizm i rossiyskaya kul'tura [Feminism and Russian culture] / G.A. Tishkin, ed. Saint Petersburg: SPbGAK: 138-167.

Tolts M.S. (1977). Brachnost' naseleniya Rossii v kontse XIX-nachale XX v. [Nuptiality of the population of Russia in the late XIX-early XX century] // Brachnost', rozhdaemost', smertnost' v Rossii i v SSSR [Nuptiality, fertility, and mortality in Russia and in the USSR] / A.G. Vishnevsky, ed. Moscow: Statistika: 138-153.

Tomilin S.A. (1987). K voprosu o plodovitosti krest'yanki i vliyanii ee na detskuyu smertnost' [On the question of peasant fertility and its effect on child mortality] // Sovetskaya demografiya za 70 let [Soviet demography in 70 years] / T.V. Rjabushkin, ed. Moscow: Nauka: 107-109.

Tretiy s"ezd Obshchestva russkikh vrachey v pamyat' N.I. Pirogova v S.-Peterburge (3-10 yanvarya 1889 g.): polnyy otchet [The third Congress of the N.I. Pirogov Society of Russian physicians, St. Petersburg (3-10 January 1889): full report] (1889). Saint Petersburg. 441 p.

Trubnikov V.V. (1858). Rezul'taty narodnykh perepisey v Ardatovskom uezde Simbirskoy gubernii [The results of the national census in the Ardatov district of Simbirsk province] // Sbornik statisticheskikh svedeniy o Rossii, izdavaemyy RGO [Collection of statistical information on Russia, published by RGO]. 3. Saint Petersburg: Tipografiya Morskogo ministerstva: 343-427.

Uspensky G.I. (1954). Polnoe sobranie sochineniy [Complete collection of works]. V 14 t. [In 14 vol.]. 8. Moscow: Izdatel'stvo Akademii nauk SSSR. 647 p.

Van-der-Born R. (1909). Izbezhanie materinstva v svyazi s gigienoy braka, s tochki zreniya sovremennoy meditsiny [The avoidance of maternity in connection with the hygiene of marriage, from the point of view of modern medicine]. Saint Petersburg: Tipografiya tovarishchestva «Gramotnost'». $144 \mathrm{p}$.

Veremenko V.A. (2007). Dvoryanskaya sem'ya i gosudarstvennaya politika Rossii (vtoraya polovina XIX - XX v.) [The noble family and the state policy of Russia (second half XIXXX century)]. Saint Petersburg: Evropeyskiy dom. 622 p.

Vigdorchik N.A. (1914). Detskaya smertnost' sredi peterburgskikh rabochikh [The infant mortality rate among St. Petersburg workers] // Obshchestvennyy vrach [Public doctor]. 2: 212-253.

Vishnevsky A.G. (1977). Rannie etapy stanovleniya novogo tipa rozhdaemosti v Rossii [Early stages of the formation of a new type of fertility in Russia] // Brachnost', rozhdaemost', smertnost' v Rossii i v SSSR [Marriages, births and deaths in Russia and in the USSR] / A.G. Vishnevsky, ed. Moscow: Statistika: 105-135.

Vishnevsky A.G. (2005). Demograficheskaya revolyutsiya [The demographic revolution] // Vishnevskij A.G. Izbrannye demograficheskie trudy [Selected demographic works]. Moscow: Nauka. 1: 5-216.

Vishnevsky A.G., M.S. Tolts (1988). Evolyutsiya brachnosti i rozhdaemosti v sovetskiy period [The evolution of nuptiality and fertility in the Soviet period] // Naselenie SSSR za 70 let [The population of the USSR for 70 years] / L.L. Rybakovsky, ed. Moscow: Nauka: 75-114.

Vladimirsky-Budanov M. F. (1900). Obzor istorii russkogo prava [An overview of the history of Russian law]. Kiev; Saint Petersburg: N.Ya. Golobin. 674 p.

Voenno-statisticheskiy sbornik [Military statistical collection] (1871). 4. Rossiya [Russia]. 1. / N.N. Obruchev, ed. Saint Petersburg: Voennaya tipografiya. 922 p. 
Vojcehovsky A.I. (1888). Ob odnom narodnom abortivnom sredstve [About one people's abortion method] // Protokoly i trudy obshchestva elisavetgradskikh vrachey za 1886-1887 gg. [Minutes and papers of the society Elisavetgrad doctors for 1886-1887.] Saint Petersburg: $37-41$

Vosproizvodstvo naseleniya SSSR [The reproduction of the population of the USSR] (1983) / A.G. Vishnevsky, A.G. Volkov, eds. Moscow: Finansy i statistika. 303 p.

Vsepoddanneyshiy otchet ober-prokurora Svyateyshego Sinoda po vedomstvu pravoslavnogo ispovedaniya za 1842-1914 god [The most humble report of the chief procurator of the Holy Synod of the institution of the Orthodox confession for 1842-1914] (1842-1914). Saint Petersburg: Sinodal'naya tipografiya.

Vsepoddanneyshiy otchet ober-prokurora Svyateyshego Sinoda po vedomstvu pravoslavnogo ispovedaniya za 1913, 1914 god [The most humble report of the chief procurator of the Holy Synod of the institution of the Orthodox confession for 1913, 1914] (1915). Saint Petersburg: Sinodal'naya tipografiya. $142 \mathrm{p}$.

Zabolotnaja L.P. (2010). Imeli li zhenshchiny pravo na razvod v Moldove XVI-XVII vv.? [Did women have had the right to divorce in Moldova in the XVI-XVIIth centuries?] // Sotsial'naya istoriya. Ezhegodnik 2009 [Social history. Yearbook 2009]. Moscow: Aleteyya: 9-22.

Zakharov S.V. (2002). Rozhdaemost' v Rossii: pervyy i vtoroy demograficheskiy perekhod [The birth rate in Russia: the first and second demographic transition] // Demograficheskaja modernizacija, chastnaja zhizn' i identichnost' v Rossii [Demographic modernization, private life and identity in Russia]. Tezisy dokladov [Abstracts]. Nauchnaya konferentsiya [Scientific conference]. Moskva, 27-28 fevralya [Moscow, February 27-28]. Moscow: TsDECh INP RAN, Institut etnologii i antropologii RAN: 19-26.

Zakharov S.V. (2003). Demograficheskiy perekhod i vosproizvodstvo pokoleniy v Rossii [Demographic transition and the replacement of generations in Russia] // Voprosy statistiki [Questions of statistics]. 11: 3-12.

Zhbankov D.N. (1922). O polovoy zhizni uchashchikhsya zhenshchin [On the sexual life of female students] // Vrachebnoe delo [Medical Practice]. 10/12. 